\title{
XV. Yüzyılda Muhammed Tarafından Yazılan Manzum Sîret'ten Bahseden Çalışmalar ve Sîret'in Nüsha Kayıtları-II
}

\author{
Prof. Dr. Hasan Ali Esir \\ Recep Tayyip Erdoğan Üniversitesi, Fen-Edebiyat Fakültesi \\ Türk Dili ve Edebiyatı Bölümü \\ hasan.esir@erdogan.edu.tr
}

Öz

Sirret, XV. yüzyılda Muhammed adlı bir müellif tarafından yazılmıştır. İncelenen kaynaklarda Muhammed hakkında bilgi bulunmamaktadır. Sîret'in yurt içinde ve yurt dışında çok sayıda yazma nüshası bulunmaktadır. Ayrıca 19. yüzyılın sonları ile 20. yüzyılın başlarında taş baskıları da yapılmıştır. Nüshaların pek çoğu, müellifi tespit edilemeyecek kadar eksiktir. Müellifi bilinenlerin de bir kısmı dikkatsizlik nedeniyle kayıtlara farklı adlarla geçirilmiştir. Bunun sonucunda eserin adı yirmi iki, müellifinin adı da yirmi farklı şekilde kayıtlara geçirilmiştir. Bu karışıklık nedeniyle eser üzerinde yapılan kimi çalışmalarda yanlışlar göze çarpmaktadır. Sîret'in zaman içinde istinsahı ve taş baskıları yapılırken esere ekleme ve çıkarmalar yapıldığı anlaşılmaktadır. Bu durum ortaya sağlam bir metnin konulmasını güçleştirmektedir. Makalede Sîret'ten bahseden çalışmalar hakkında bilgi verilecek ve tespit edilen nüshaların kayıtları değerlendirilecektir. Ayrıca kayıtlardaki eksikler ve yanlışlar araştırılarak yanlış kayıtların sebepleri anlatılacaktır.

Anahtar Kelimeler: Sîret, siyer, Muhammed, nüsha kayıtları, değerlendirme.

\section{Studies on the Poem Sîret Written by Muhammad in the 15th Century and Written Copies of Sîret-II}

\begin{abstract}
Sirret was written by an author named Muhammed in the 15th century. There is not any information about Muhammad in the sources examined. Sîret has many copies in Turkey and abroad. In addition, stone prints were made in the late 19th and early 20th centuries. Many of the copies have missing parts to detect its writer. Some of the copies whose writer is known have been recorded in different names due to carelessness. As a result, the name of the work and the writer's name have been recorded in twenty-one and nineteen different ways, respectively. Because of this confusion, some studies conducted on the work are inaccurate. It is understood that while copies and stone prints were being created, some additions and subtractions were made to the work. This situation makes it difficult to put forward a solid text. In the article, information will be given about the studies on Siret and the records of the identified copies will be evaluated. In addition, the deficiencies in the records will be investigated and the reasons for the wrong records will be explained.
\end{abstract}

Keywords: Sîret, siyer, Muhammad, written copies, evaluation. 


\section{GíRIŞ}

"Siyer"1, sözlükte "davranış, hâl, yol, âdet, bir kimsenin ahlâkı, seciyesi ve hayat hikâyesi" gibi anlamlara gelen "sîret" kelimesinin çokluğudur. "Sîret" ve "siyer" Hz. Peygamber' in hayatı, onun hayatını konu edinen bilim dalı ve bu dalda yazılan eserler için terim olarak kullanılmıştır. "Savaş yeri, savaş ve savaş hikayeleri" anlamındaki "mağzât" kelimesinin çokluğu olan "megâzî" ise Resûl-i Ekrem'in gazve ve seriyyelerinin tarihine ve bu konuda yazılan kitaplara isim olmuş, siyer kelimesinin eş anlamlısı hâlinde hem kendi başına hem siyerle birlikte kullanılmıştır. (Fayda, 2009, s. 319). "Sîret"in zıddı "sûret"tir. Türk edebiyatında "sîret" yerine daha ziyade "siyer" teklik gibi kullanılmıştır.

İlk siyer kitapları İbn İshâk (öl. 151/768) Kitâbü'l-megââ̂, Vâkıdî (öl. 207/823), Kitâbü'lmegâzî̀, İbn Hişâm (öl. 218/833) es-Sîretü'n-nebeviyye, İbn Sa'd (öl. 230/845) Kitâbü't-tabakâti'lkebîr, Belâzürî (öl. 279/892-93) Ensâbü'l-eşrâf gibi Arap müelliflere aittir. Türk edebiyatında ise ilk siyerler tercüme-teliftir. Türkçe ilk siyer kitabı XIV. yüzyılın ikinci yarısında Darîr tarafından manzum-mensur olarak yazılan Sîretü'n-nebî'dir. Bugünkü bilgimizle tamamı manzum olan ilk Türkçe sîret (siyer) ise nüshalarını tanıtıp değerlendireceğimiz XV. yüzyılda Muhammed adlı biri tarafından yazılan Sîret'tir. Eserin "Âgâz-1 Kitâb-1 Sîret-i Terceme Be-Nazm" (MC 5 $\left.{ }^{\mathrm{b}}\right)^{2}$ başlı̆̆ında tercüme olduğu belirtilmiştir. Ancak incelendiğinde tercümenin yanında esere ilaveler de yapıldığı görülmektedir. Eser rivayetler üzerine kurulmuştur. Bu rivayetlerden beş tanesi Ebü'l-Hasan Bekrî'ye (öl. VII. / XIII. yy.?) ${ }^{3}$ aittir (MC 9a / b 1, 266 / b. 5, 305 / b. 4, 358 / b. 7, 445b / b. 3). Bunun yanıda eserde "râvîlerden hoş rivâyetler kılalum", "râvî aydur", "râvî dir", "râvîler kıldı rivâyet", "râvîler virdi bize böyle haber", "râvîler şöyle rivâyet eyledi", "didi râvî", "râvîler şöyle didiler" şeklinde kime ait olduğu açıç̧a belli olmayan rivayetler de vardır. Siyer konusu Türk edebiyatında daha sonra bir tür olarak yer almıştır.

\section{Muhammed (XV. yy.)}

Sîret'in müellifi Muhammed adında biridir. İncelediğimiz kaynaklar Muhammed hakkında bilgi vermemişlerdir. Nerede, kaç tarihinde doğduğu, eğitimi, ailesi, çevresi, mesleği, başka eser(ler)i olup olmadığı ve ölüm tarihi konularında hiçbir bilgi yoktur. Bununla birlikte Sîret'inin bazı beyitlerinden hakkında kısa bilgiler çıkarmak mümkündür. Müellif, eserinin başında ve sonunda iki yerde adının Muhammed olduğunu söylemektedir (MC 4a / b. 9, 493a / b. 4). Aşağıda da değinileceği gibi, eserini 872 / 1467'de tamamladığına göre en erken bu tarihte vefat etmiş olmalıdır. Bu bilgilerden onun XV. yüzyılda yaşadığı

\footnotetext{
${ }^{1}$ Müellif, eserinde yirmi beş yerde eserinin adını "Sîret" olarak zikretmiştir; “Siyer"i ise hiç kullanmamıştır. Bundan dolayı makalede "sîret" kullanımı tercih edildi.

2 Makalede MC kısaltması İstanbul Büyükşehir Belediyesi Atatürk Kitaplığı Demirbaş MC_Yz_O_0053'te kayıtlı nüsha olup verilen varak ve beyit numaraları bu nüshaya göredir.

${ }^{3}$ Ebü'l-Hasen Ahmed b. Abdillâh b. Muhammed el-Bekrî [öl. VII/XIII. yüzyılın sonları (?)]. İslâmiyet'in ilk yıllarına dair hayal mahsulü hikâyeleriyle tanınan bir müellif. Bekrî’nin hayatına dair bilgi bulunmadığı gibi hangi yüzyılda yaşadığı da kesin olarak belli değildir. Zehebî V./XI. yüzyılda yaşadığını tahmin etmekte, III./IX. yüzyılın ortalarında öldüğünü kaydeden Luvîs Şeyho ise bu bilgiyi hangi kaynaktan aldığını belirtmemektedir. F. Rosenthal onun VII./XIII. yüzyılın sonlarına doğru yaşamış bazı müelliflerden nakiller yaptığını söyleyerek bu yüzyılda yaşamış olabileceğini ve ona nisbet edilen eserlerin hepsinin kendisine aidiyetinin de kesin olmadığını ileri sürmektedir. Bekrî'nin "Basralı vâiz" şeklindeki unvanına itibar edilecek olursa muhtemelen Irak'ta yaşamıştır. Hz. Peygamber'in hayatını anlatan Sîretü'n-neb̂̂ adlı eseri hayalî hikâyelerle ve yanlış bilgilerle dolu olduğu için okunması bir fetva ile yasaklanmıştır. Zehebî onu "iftira etmekten ve yalan söylemekten utanmayan, hatta Müseylimetülkezzâb’dan daha yalancı biri" olarak tavsif etmekte, yazdığı şeylerin hiçbir mesnedi bulunmadığını veya anlattığı olaylara pek çok uydurma bilgi ilave ettiğini söylemektedir (Türkiye Diyanet Vakfı İslam Ansiklopedisi. Cilt 5. s. 366).
} 
anlaşılmaktadır. Bu mahtut bilgilere dayanarak doğum tarihi ile ilgili fikir yürütmek tahminden öteye gitmez.

\section{Sanat Anlayışı}

Müellifin sanat anlayışıyla ilgili öz bilgiler yine Sîret'ten çıkarılabilir. Sanat yapmak iddiasında olmadığını söylemektedir. Şair olmadığını söyleyip şâirlik adından kaçmaktadır. Şairane şiire toprak saçmaktadır. Şeriat yolunu seçmiştir. Şiire ihtiyacı yoktur. Bununla birlikte şiir sanatının inceliklerini, usul ve füruunu bihakkın bilmektedir (MC 8a / b. 15-17, $8^{\text {b }}$ / b. 1). Bütün bunlardan onun, şiiri amaç değil araç olarak kullandığı söylenebilir. Sîret'inden hareketle derviş meşrep biri olduğu anlaşılmaktadır. Muhammed'de, Dursun Fakih (öl. 726/1326) ve Âşık Paşa (öl. 733/1332) tesiri görülür. Sîret'te Dursun Fakih'ten alıntılar vardır. ${ }^{4}$

\section{Eserin Adı, Yazılış Amacı ve Tarihi}

Eserin adı yirmi beş yerde Sîret olarak geçmektedir. "Siyer" biçiminde kullanım ise yoktur. Muhammed, eserini Hz. Peygambar'in mucizelerini ve övgüsünü anlatmak için yazdığını söylemektedir (MC 8a / b. 12, 13). Şiir heveslisi değildir. Ancak ansızın bir aşk parıltısı ile coşmuş, eksik fazla düşünmeden Sîret'i yazmaya koyulmuştur (MC 8b / b. 2-7). Eserini Türkçe yazmış (MC 492a / b. 10) ve hicri 872 / 1467 yılı Rebiü'l-evvel (Berlin nüshasında Rebiü'l-âhir) ayı ilk günü Cuma, sabah vaktinde tamamlamıştır (MC 492a / b. 1113).

\section{Eserden Bahseden Çalışmalar}

Sîret'le ilgili bilgiler çok farklı şekillerde kütüphane kayıtlarına girmiştir. Bilhassa eksik nüshalardaki bilgilir farklıdır. Bundan dolayı ortada karmakarışık bir tablo bulunmaktadır. Bu karışıklık, eser üzerinde yapılan kimi çalışmalarda yanlışlara sebep olmuştur. Kütüphane kayıtlarının dışındaki çalışmalar, nüshaların tespiti, tanıtımı ve metin çalışmaları şeklindedir. Bu çalışmalardaki bazı bilgiler, karışık ve yanlış olup çoğu birbirinin tekrarıdır. Bunlardan en dikkat çekeni Sîret'in adı ve müellifinin kim olduğu konusudur. Bu çalışmalar yayım tarihlerine göre şöyledir:

1.Vasfi Mahir Kocatürk, Türk Edebiyatı Tarihi: Kocatürk, eserinde Sîret hakkında bilgiler vermiştir. Önce Sîret'in 1892 tarihli taş baskısı üzerinden eserin Türk kültürü ve edebiyatı açısından önemine dikkat çekmiş, muhtevasını Sîret'ten aldığı beyitlerle özet olarak vermiştir. Siyer türü eserlerin geceleri kahvelerde ve evlerde bir kişi tarafından makamla okunduğuna birçok kimseler tarafından dinlendiğine ve bu geleneğin son zamanlara kadar devam ettiğine işaret ederek Sîret'in millîliğine vurgu yapmıştır (Kocatürk, 1970, s. 269-274). Vasfi Mahir Kocatürk, daha sonra Sîret'in yazıldığı tarihi ve müellifini tespit edemediğini, "Eserin yazarı ve yazıldığı zaman belli değildir." (Kocatürk, 1970, s. 274) sözleri ile dile getirmiştir. Kocatürk, bu ifadelerinden sonra, ki bizim tespitimize göre yazma nüshalarda olmayıp eserin taş baskısını yapanlarca esere ilave edilen, "Nâzım-ı Merhûmun Tazarruudur" başlıklı manzumde "Kemîne bendenüzdür Abdurrahmân denildiğine göre yazarın adı Abdurrahman'dır." (Kocatürk, 1970, s. 274) diyerek tereddütlü bir tavır sergilemiştir. Vasfi Mahir Kocatürk'ün, dönemin imkanları ölçüsünde böyle bir değerlendirmede bulunması önemli bir gayret olmakla birlikte, eksik / yanlış bir bilgidir. Vasfi Mahir Kocatürk, Sîret hakkındaki bilgileri taş baskı nüsha üzerinden verdiği için eserin müellifini ve telif tarihini tespit edemediği anlaşılmaktadır.

$\overline{{ }^{4} \mathrm{Bu} \text { konuda ayrı bir çalışma yapılacaktır. }}$

SEFAD, 2019; (42): 107-130 
2. Massad Süveylim Ali el-Shaman, Türk Edebiyatında Siyerler ve İbn Hişam'ın Siyer'inin Türkçe Tercümesi. C. 1: Eser / çalışma, İbn Hişâm'ın Siyer'inin Türkçeye tercümesi çerçevesinde hazırlanmış bir doktora tezidir. Massad Süveylim Ali el-Shaman, tezinin 1. Bölümü'nde Türk Edebiyatında Siyer Kitapları başlığı altında Muhammed'in Sîret'i hakkında bilgiler vermiştir. Bu bilgileri, eserin taş baskı ve Berlin nüshalarından yararlanarak hazırlamıştır. Sîret' in taş baskıları, müdahaleler sonucu, yazma nüshalara göre farklılık arz etmektedir. Bundan dolayı el-Shaman da Kocatürk gibi Sîret'in müellifinin kim olduğu konusunda tereddüt yaşamıştır. el-Shaman, Sîret'in XV. yüzyılda kaleme alındığını, Muhammed isimli bir zat tarafından nazmedildiğini, eserin müellifinin Muhammed olduğunu tespit etmiştir (el-Shaman, 1982, Cilt 1, s. XLVIII). Ancak taş baskı nüshada geçen "Nâzım-ı Merhûmun Tazarruudur" başlığı altındaki manzumede geçen Abdurrahman isminin karışıklığa sebep olduğunu, "Müellifin isminin Abdurrahman olduğu anlaşılabilmektedir. Müellifin ismi Muhammed olsun veya Abdurrahman olsun, hayatı hakkında hiçbir bilgiye rastlanmamıştır." (el-Shaman, 1982, Cilt 1, s. XLIX) diyerek bu tereddüdünü dile getirmiştir.

3. Engin Yılmaz, Gazavâtnâmeler ve Niyâzî̀nin Gazavât-ı Neb̂̂'si: Çalışma, Millet Kütüphanesi Ali Emiri Efendi Manzum 1398'de kayıtl eksik bir Sîret nüshasından hareketle Marmara Üniversitesi Sosyal Bilimler Enstitüsü Türk Dili ve Edebiyatı Ana Bilim Dalı Türk Dili Bilim Dalında 1995'te yapılmış Yüksek Lisans tezidir. Engin Yılmaz, tezinin Girişinde gazavâtnâmeler konusunu ele almış ve teze konu olan nüshayı çeşitli yönleriyle tanıttıktan sonra nüshanın muhtevasını teşkil eden Huneyn Savaşı, Hz. Ali'nin Karalar ile Savaşı, Mute Harbi, Tebük Harbi ve Hz. Peygamber'in Vefatı bölümlerinin özetlerini vermiştir (Yılmaz, 1995, s. 5, 14). Engin Yılmaz, eserin müellifi hakkındaki bilgilerin kifayetsizliğine dikkat çekmiş ve müellifin adının 2363. beyitte "Niyâzî" olarak geçtiğini belirtmiştir (Yılmaz, 1995, s. 14). Yılmaz, nüshada 2363. beyti "Gice gündüz işledügüm hep günâh / Rahmet umaram Niyâzî rû-siyâh "şeklinde tespit etmiştir (Yılmaz, 1995, s. 14, 76). Nüshanın 1a yaprağında "Nâzımının ismi Niyâzî'dir. 959 [1551] senesinde telif etmiştir." notu vardır. Nüshanın sonunda 64b'de de "El- fakîr el-hakîr Seyyid Abdullah yazan dahı Tanrı rahmet eylesün ana dahı. Temmet. Yevmu cum'a fî şehri Receb fî 23 sene isnâni işrûn mieteyni elfun" temmet kaydı bulunmaktadır. Öyle anlaşılıyor ki nüsna 959 [1551] tarihli bir nüshadan Seyyid Abdullah adında biri tarafından 1222'de [1807] istinsah edilmiştir. Eser müellifinin ismi, nüshanın 63b/12. beytinde "Muhammed" olarak geçmektedir. Tezi hazırlayan Engin Yılmaz, 63º $/ 3^{\prime}$ te geçen (tezde 2363 . beyit) Niyâzî / niyâzı kelimesinin işaretiyle ve 1a yapraktaki "nâzımının ismi Niyâzîdir" notunun delaletiyle eser müellifinin Niyâzî olduğu sonucuna varmıştır. Gerçekte nüsha Muhammed Sîret'inin eksik bir nüshasıdır. ${ }^{5}$

4. Prof. Dr. Âmil Çelebioğlu, Muhammediye I: Âmil Çelebioğlu eserinde Muhammediye Tipindeki Eserler başlı̆̆ altında, Muhammed'in Sîret'ini Topkapı Sarayı Müzesi Kütüphanesinde 2287 H. 233 numarada kayıtlı nüsha üzerinden değerlendirmiştir. $\mathrm{Bu}$ değerlendirmede nüshanın 327 yaprak olduğunu, Mehmed adında birisine ait olup muhtemelen XVII. yüzyıl mahsulü olduğunu söylemiştir. Mehmed için de "müellif veya mütercim" ifadesini kullanmıştır. Sîret'in Muhammediye'ye benzediğini ve iki farklı vezinle

\footnotetext{
${ }_{5}^{5}$ Bu çalışmanın Yök Tez Sayfası'nda erişim izni bulunmamaktadır. Nüshanın kayıtlı olduğu kütüphanedeki kayıtları / bilgileri de erişime açık değildir. Çalışmadan daha sonra haberimiz oldu. Bu nedenle "XV. Yüzyılda Muhammed Tarafından Yazılan Manzum Sîret'in Nüshaları-I" de bu çalışmadan bahsedilmedi.
} 
yazıldığını da belirtmiştir (Çelebioğlu, 1996, Cilt 1, s. 197). Âmil Çelebioğlu, Sîret müellifini Muhammed yerine Mehmed şeklinde tespit etmiştir.

5. Prof. Dr. Necla Pekolcay, Mevlid (Vesîletü'n-Necât): Necla Pekolcay, eserinde tespit ettiği 63 Türkçe mevlidi yazarlarına göre alfabe sırası ile vermiştir. Bu sıralamada ikinci sırada Abdurrahman yer almaktadır. Abdurrahman'ın eseri için "Eser bir siyer-mevlid olup, XVI. asırda yazılmıştır; bu eserin de elimizde iki yazması vardır." (Pekolcay, 1997, s 40). şeklinde kısa ve muğlak bir açıklaması vardır. Necla Pekolcay'ın sözünü ettiği müellif ve eser Muhammed ve Sîret'idir.

6. Yıldıray Kaplan, Erzurumlu Kadı Mustafa Darîr'in Kitâb-ı Siyer-i Nebî'si: Çalışma yüksek lisans tezidir. Ankara Üniversitesi Sosyal Bilimler Enstitüsünde 2006'da yapılmıştır. Tezde siyer konusu genel olarak ele alınmış, daha sonra Kadı Darî' in Siyer'i çeşitli açılardan tahlil edilmiştir. Yıldıray Kaplan'ın, tezinde XV. Asır siyerlerini ve müelliflerini sıralarken ikinci sırada "Siyer-i Nebi: IX/XV. asır şairlerinden Muhammed (Abdurrahman)" (Kaplan, 2006, s. 25) künyesi ile zikrettiği eser Muhammed'in Sîret'idir. Kaplan, tezinde daha sonra, "IX/XV. asır siyer müelliflerinden Muhammed (veya Abdurrahman) isimli bir müellif tarafından kaleme alınan 'Siyer-i Nebi' adlı eser, Darîr'in siyerinin manzum hale getirilmiş şeklidir." (Kaplan, 2006, s. 99) sözleriyle eserin Darîr'e ait olduğunu söylemiştir.

7. Prof. Dr. Mustafa Uzun, Türkiye Diyanet Vakı Íslam Ansiklopedisi "Siyer ve Megâzî” Maddesi "Türkçe Siyer Kitapları" Bölümü: Mustafa Uzun, söz konusu maddede Telif Siyer Kitaplarını sıralarkan 2, 4, 5 ve 7. sıralarda yer verdiği siyerler hakkında şu bilgileri vermiştir: “2. Molla Velî, Manzum Siyer-i Nebî. Amasya Beyazit İl Halk Kütüphanesi'nde nüshası bulunan (nr. 1460) XV. yüzyıla ait bu eser yaklaşı 10.000 beyittir. 4. Siyerü'n-nebî. Tahminen XVI. yüzyıla ait yaklaşık 3000 beyitlik bu eserin Mehmed adlı yazarı hakkında bilgi bulunmamaktadır (Süleymaniye Ktp., Bağdatlı Vehbi Efendi, nr. 1544). 5. Abdurrahman, Siyerü'n-nebî. 10.000 beyti aşmaktadır (Süleymaniye Ktp., Yazma Bağışlar, nr. 3916). 7. Abdullah Zâhidî, Manzum Siyer-i Nebî (Köprülü Ktp., Ahmed Paşa, nr. 234)" (Uzun, 2009, s. 325). Bu şekilde sıraladığı ve farklı olduğunu söylediği bu dört siyer, Muhammed'in Sîret'inin farklı nüshalarıdır.

8. Prof. Dr. Nihat Öztoprak, “Türk Edebiyatında Manzum Siyerler": Nihat Öztoprak, yayımlanan tebliğinde "Diğer Manzum Siyerler" alt başlığında Darîr, Yazıcıoğlu ve Münîrî̀nin dişındaki Türkçe manzum siyer yazıcılarını ve eserlerini sıralarkan; 1. sırada Molla Velî, Manzum Siyer-i Nebî, 2. sirada Abdurrahman (Muhammed), Siyerü'n-Nebî, 5.

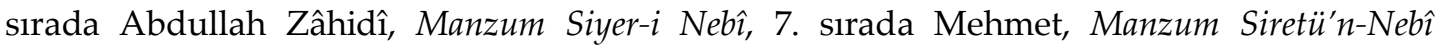
Tercümesi (Öztoprak, 2010. s. 67, 68) şeklinde bir yol takip etmiştir. Dört farklı yazar ve eser olarak gösterilen bu siyerler Muhammed'in Sîret'inin farklı nüshalarıdır.

9. Prof. Dr. Fatih Köksal, Mevlid-nâme: Fatih Köksal, Mevlid-nâme adlı eserinde “I.III.IV. Mevlidi Olmadığı Hâlde Kendisine Mevlid Atfedilen Şairler A. Muhtelif yayınlarda kendisine mevlid atfedilen şairler" alt başlı̆ı̆ında ilk sıraya Abdurrahman'ı koyarak şu tespitlerde bulunuyor:

1. Abdurrahmân: Necla Pekolcay eserin bir siyer-mevlid olup XVI. yüzyılda yazıldığını ve iki nüshass bulunduğunu bildirmektedir (Pekolcay, 1997, s. 40). Bir yazma nüshası şahsî kütüphanemizde bulunan eser, birçok defa baskısı da yapılmış olan Manzum "Siyer-i Neb̂̀"dir. Müellifinin Abdurrahman'ın yanısıra Muhammed mahlasım da kullandığı siyer, XVI. değgil XV. yüzyılda kaleme alınmış olup yaklaşık 15 bin beyit tutarında mücessem bir mesnevidir. Bu eseri 
mevlid kabul edersek diğer manzum siyerleri de mevlid kabul etmemek için bir sebep kalmaz (Köksal, 2011, s. 78).

Fatih Köksal'ın, "Müellifinin Abdurrahman'ın yanısıra Muhammed mahlasını da kullandığı siyer" dediği eser Muhammed'in Sirret'idir.

10. Makbule Özmen, Za'ifî́nin Manzum Siyer-i Nebî'sinin Transkripsiyonlu Çevirisi ve İncelenmesi: Çalışma, Yüksek Lisans tezi olup Millî Kütüphane, 06 Mil Yz A 2839'da yanlış olarak Zaifî adına kayıtlı Muhammed'in eksik bir Sîret nüshasından hareketle yapılmıştır. Teze konu olan nüsha başlıksız olarak Mekke'nin Fethi Bölümü ile başlayan, Huneyn (tezde 695. beyitten sonra) ve Müzelzel bin Menâzil (tezde 1872. beyitten sonra) Gazaları ile devam edip tamamlanan bir nüshadır. Bu iki bölüm de başlıksızdır. Makbule Özmen, tez başlığında, Zaifî ismine bağlı kalmakla birlikte tezinin ikinci bölümünde eserin kime ait olduğu konusunda bazı tereddütlerini dile getirmiştir. Katalogda Zaifî adının yanlış olabileceğini söylemiş, bununla birlikte eserin kime ait olduğu konusunda da fikir yürütülemediğini belirtmiştir (Özmen, 2011-2012, s. 18). Tezde zikredilen “Abdurrahman (Muhammed), Siyer-i Nebî" ve "Molla Velî, Manzum Siyer-i Nebî" (Özmen, 2011-2012, s. 14, 15) Muhammed'in Sîret'inin iki farklı nüshalarıdır.

11. Altan Can, Muhammed'in Sîretü'n-Nebî'si (1-3422. Beyit) (İnceleme-Metin): Çalışma Dicle Üniversitesi Eğitim Bilimler Enstitüsü Türk Dili ve Edebiyatı Eğitimi Bilim Dalında Altan Can tarafından 2014'te yapılmış Yüksek Lisans tezidir. Yazar Sîret'in taş baskı nüshalarının hemen hemen her kütüphanede ve hususi ellerde mevcut olduğunu gözlemlediğini, ayrıca yirmi dört farklı yazma nüshasını tespit ettiğini söylemektedir (Can, 2014, s. 20). Tez Sîret'in baştan Kissa-i Mi'râc-1 Resûlüllâh bölümünün sonuna kadarki 3422 beyti içermektedir. Sîret'in ikisi taş baskı, dördü yazma toplam altı nüshası üzerinden hazırlanmıştır. Altan Can, XV. Asır siyerlerini ve müelliflerini sıralarken ikinci sırada zikrettiği ve dipnotta "üzerinde çalıştığımız eserdir" dediği siyeri "Siyer-i Nebi: IX/XV. asır şairlerinden Muhammed (Abdurrahman)" (Can, 2014, s. 8) künyesi ile vermiştir. Tezde "Diğer Yazma Nüshalar" başlığı altındaki sıralamada, "m) Kitab Siyer El Nebîy adı ile Edirne Selimiye Kütüphanesi'nde (22 Sel 2532) numara ile kayıtlı el yazma eser olup 270 varaktan ibarettir." şeklinde tanıttığı nüsha yazma değil, taş baskıdır. Yine XIX. Asır siyerlerini ve müelliflerini sıralarken on ikinci sırada zikrettiği" Kitâb-1 Siyer-i Nebî: Abdurrahman" (Can, 2014, s. 14) Muhammed'in Sîret'inin taş baskı nüshasıdır.

12. Bayram Özfırat, Türk Edebiyatının Manzum İlk Siyeri: Velî'nin Sîretü'nNebî’si: Bayram Özfırat, makalesinde, siyer ilminin doğuşu ve genel olarak siyer hakkında bilgi vermiştir. Daha sonra "Kaynaklarda Velî’nin Sîretü'n-Nebî'si" başlığı altında eser üzerinde Vasfi Mahir Kocatürk, Massad Süveylim Ali el-Shaman ve Âmil Çelebioğlu'nun değerlendirmelerine yer vermiştir (Özfırat, 2014, s. 105-110). Özfırat, makalesinde "Eski tezkirelerde ve 15. yüzyılda yazılmış diğer kaynaklarda Muhammed veya mahlası olan Velî adında bir şair veya siyer yazarı ile karşılaşılmamıştır.", "Velî’nin Yaşadığı Devir ve Hayatı", “Müellif mahlas olarak Velî̀yi kullanmıştır." (Özfırat, 2014, s. 105, 109, 110) ifadelerinden Sîret müellifinin kim olduğu konusunda tereddüt yaşamıştır.

13. Altan Can, Muhammed'in Siret'ün-Nebî'sindeki Mi'râç Mucizesi Bölümü Üzerine: Altan Can'ın Sîret konusundaki ikinci çalışmasıdır. Yazar, makalesinde Girişten sonra Sîret'in Miraç Mucizesi Bölümü'nü günümüz Türkçesiyle nesre çevirmiş ve 
incelemiştir (Can, 2015, s. 259-317). Makale yazarın Yüksek Lisans tezinden ürettiği bir çalışmasıdır.

14. Bayram Özfırat, 15. Yüzyıl Şairlerinden Muhammed'in Sîretü'n-Nebîsi: Çalışma Baram Özfırat'ın Dotrora tezi olup Sîret konusundaki ikinci çalışmasıdır. Marmara Üniversitesi Sosyal Bilimler Enstitüsünde 2016'da yapılmıştır. Yazar, Tez'inin Özet'inde “... eser 15. yüzyılda Muhammed adında biri tarafından yazılmıştır. 'Muhammed' isminin müellifin asıl adı olduğu tahmin edilmektedir. Müellif eserinde, mahlas olarak Velî'yi tercih etmiştir."(Özfırat, 2016, s. XVI) diyerek makalesindeki tereddütlerine devam etmiştir. Bu teredütlerini Tez'inin ilerleyen bölümlerinde de sürdürülmüştür (Özfırat, 2016, s. 68, 69). Gerçekte bazı nüshalarda geçen Velî, müellifin mahlası değil, Sîret müstensihlerinden birinin adıdır. Sîret nüshaları karşılaştırıldığında bu husus açı olarak anlaşılmaktadır. Tez'de karşılaştırmalı metin, İstanbul Büyükşsehir Belediyesi Atatürk Kitaplığı Demirbaş MC_Yz_O_0053, Konya Mevlana Müzesi Yazmaları No 1169 ve İstanbul Üniversitesi Nadir Eserler Kütüphanesi TY No 1601'de kayıtlı nüshalardan yararlanılarak hazırlanmıştır.

15. Fatih Köse, Yazarı Bilinmeyen Bir Hz. Hatice Hikâyesi (Tenkitli Metin-İnceleme): Gazi Üniversitesi Sosyal Bilimler Enstitüsünde 2017'de üç nüshaya dayanan bir Yüksek Lisans tezidir. Fatih Köse, tezinde Tenkitli Metin Oluşturulurken İzlenen Yol başlığı altında "Eser her nüshada ayrı bir isimle isimlendirildiği ve yazarına ilişkin herhangi bir bilgiye ulaşılamadığı için 'Yazarı Bilinmeyen Bir Hz. Hatice Hikâyesi' olarak isimlendirilmiştir." (Köse, 2017, s. 28) demektedir. Sözü edilen nüshalar "Manzûme-i Hatîcetü'l-Kübrâ, Millî Kütüphane, 06 Mil Yz A 8631/2"; “Hikâye-i Hadîcetü'l-Kübrâ, Koyunoğlu Türkçe Yazmaları Koleksiyonuna 10250/a"; “Hikâye-i Seyyide Hadîcetü'l-Kübrâ Ümmü'l-Mü'minîn, Tarihi Türkî 276 yazmalar"dır. Nüshalar Muhammed'in Manzum Siyer-i Nebî'sinin Hz. Peygamber' in Hz. Hatice ile Ticareti ve Evlenmesi Bölümü'nü içermektedirler.6

16. Prof. Dr. Hasan Kavruk-Prof. Dr. İdris Kadığlu, Manzum Siyer-i Neb̂̂: Çalışma, inceleme ve metinden müteşekkil 550 sayfa olup 2017 yılında yayımlanmış kitaptır. Bu yayımda İstanbul Büyükşehir Belediyesi Atatürk Kitaplığı MC_Yz_O_0053 numarada kayıtlı nüsha esas alınmıştır. Yayıma esas olan nüshada olmayan bazı başlıkların taş baskı nüshadan alındığı ifade edilmiştir (Kavruk ve Kadığlu, 2017, s. 40). Kitapta Türkçe Telif Siyerler sıralanırken "Molla Velî, Manzum Siyer-i Nebî" ve "Abdullah Zâhidî, Siyer-i Nebi" (Kavruk ve Kadığlu, 2017, s. 15) Muhammed'in Sîret'inin farklı nüshalarıdır. Yine "Mehmed, Siretü'n-nebî" ve "Muhammed, Siyer-i Nebî" şeklinde eksik künye ile verilen ve kime ait oldukları açıkça anlaşılmayan siyerler de (Kavruk ve Kadığlu, 2017, s. 15) Muhammed'in Sîret'inin nüshaları olabilir. Eserde Sîret'in tespit edilen yirmi dört yazma ve üç taş baskısıyla ilgili bilgiler verilmiştir (Kavruk ve Kadıŏlu, 2017, s. 38-40). Bu tanıtımda “q. Kitab Siyer El Nebîy: Edirne Selimiye Kütüphanesi'nde 22 Sel 2532 numara ile kayıtlıdır,

\footnotetext{
${ }^{6}$ Fatih Köse teze konu olan Hz. Hatice Hikâyesi'nin nüshalarını tavsif ederken Konya İl Halk Kütüphanesinde 42 Kon 2061'de kayıtlı nüshanın tavsifinde üzerinde çalışma yapılamayacak şekilde tahrip olduğu için karşılaştırmada kullanılmadığını söylemektedir (Köse, 2017, s. 27). Hâlbuki söz konusu numarada kayıtlı eser başka bir Destân-ı Hadice olup yazısı, ilk dört beyit hariç, (ilk dört beyit okunamayacak derecede silik) okunaklıdır. Yine tavsifini yaptığı ve karşılaştırmaya dâhil ettiğini söylediği Konya İzzet Koyunoğlu 10250/a arşiv numarada, Süleyman Nuri b. Mehmed tarafından istinsah edilen Hikâye-i Hadîcetü'l-Kübrâ da 42 Kon 2061'de kayıtlı Destân-ı Hadice hikâyesinin başka bir nüshasıdır. Dolayısıyla Konya İl Halk Kütüphanesi 42 Kon 2061 ve Konya İzzet Koyunoğlu 10250/a arşiv numarada kayıtlı nüshaların teze konu olan Hadicetü'l-Kübrâ hikâyesi ile bir ilgisi yoktur. Tez sahibinin 10250/a arşiv numarada kayıtlı olduğunu söylediği ve tavsifini yaptığı nüsha Koyunoğlu Kütüphanesi 10731 arşiv numadada kayıtlı Hikaye-i Nikah El-Mustafa Bi Hadice olmalıdır.
} 
270 varaktan ibarettir. Müellifinin adı Abdurrahman'dır." (Kavruk ve Kadığlu, 2017, s. 39) künyesi ile verilen nüsha Muhammed'in Sîret'inin taş baskı nüshasıdır.

\section{SÎRET'İN NÜSHA KAYITLARININ DEĞERLENDİIILMESI'7}

Sirret'in yazıldığı XV. yüzyıldan XX. yüzyılın başlarına kadar çok sayıda yazma ve taş baskısının olması onun çok sevilip okunduğunu gösterir. Çalışmamızda Sîret'in yurt içinde altmış bir, yurt dışında beş olmak üzere altmış altı yazması ile birlikte dört de taş baskı nüshası tespit edilip incelendi. ${ }^{8}$ Nüshaların pek çoğu ya müstensihleri tarafından eksik bırakılmış ya da elden ele dolaştırılmak ve okunmak suretiyle tahrip olmuş, sayfaları kopmuştur. Ayrıca bazı nüshalarda tamiratta sayfalar ve bölümler birbirine karıştırılmıştır. Tahribat genellikle yazmaların baş ve son kısımlarında olup kopuklar şeklindedir. Bundan başka nüshalarda içte de eksikler bulunmaktadır. Nüshaların hemen tamamı sonradan ve içlerindeki bu eksik ve karışıklıklar dikkate alınmadan / fark edilmeden numaralandırılmıştır. Söylemek gerekir ki bu altmış beş yazmadan pek çoğu, sağlam bir metin oluşturmaya katkı sağlayacak özellikte değildir. Taş baskı nüshalarda da durum farksızdır.

Sirret'i gerek istinsah edenler ve gerekse taş baskısını yapanlar esere bazı ilaveler yapmaktan ve eseri sahiplenmekten kendilerini alamamışlardır. Mesela taş baskıların hiçbirinde sonda eserin müellifi olan Muhammed ve tespit ettiğimiz en eski nüsha olan İstanbul Büyükşehir Belediyesi Atatürk Kitaplığı MC_Yz_O_0053'te kayıtlı nüshadaki Halîfe ve Velî isimleri bulunmamaktadır. Bunun yerine taş baskılarda 361. sayfada "Nâzım-1 Merhûmun Tazarruudur" başlığı altında birkaç beyit eklenerek eserin yazarı Abdurrahman olarak değiştirilmiştir. ${ }^{9}$ Bu değişikliğin, esere ustalıkla eklendiği görülmektedir. Bunların sebepleri ve istinsahlarda esere yapılan ekleme ve çıkarmalar ayrı bir çalışma konusudur.

Yapılan araştırmalar sonucunda tespit edilen nüshalardan görüntüleri dijital ortamda olanlar indirilerek, görüntüleri olmayanlar da bulundukları kütüphanelerle irtibata geçilerek CD (Compact Disc) ortamında elde edilerek incelenmiştir. Sîret' in yazıldığ 15. yüzyıldan 20. yüzyılın başlarına kadar her yüzyılda istinsahı yapılmıştır. İstinsahı belli nüshaların yüzyıllara göre dağılımı şöyledir: 16 yüzyıl iki, 17. yüzyıl üç, 18. yüzyıl on, 19. yüzyıl on dört. Ayrıca kütüphane kayıtlarında 19 . yüzyılın sonlarında iki, 20. yüzyılın başlarında iki olmak üzere dört taş baskısı incelemeye dâhil edilmiştir. Tespit edilemeyen nüshalar da olabilir. 17. yüzyılda 1066'da [1655], 18. yüzyılda 1181'de [1767], 19. yüzyılda 1250 'de [1834] ve 1262'de [1845] ikişer defa çoğaltılmıştır. İstanbul Büyükşehir Belediyesi Atatürk Kitaplı̆̆ Demirbaş MC_Yz_O_0053'te kayıtlı nüsha iki kitap şeklinde olup tespit edilen nüshalar arasında istinsahı 939 [1532] tarihi ile en eski olanıdır. Birinci kitap baştan Mikdâd'ın Müsülman Olması Bölümü'ne kadarki kısımdır. İkinci kitap da bu bölümden sonrasıdır.

Sîret nüshalarının bir kısmı tahrip olmuştur. Bir kısmı da baştan, sondan ya da muhtelif yerlerinden kopuk / eksiktir. Nüshaların tahrip olmaları çok okunmaları ve elden ele dolaştırılmaları sonucu olduğu söylenebilir. Asırlar içinde yapılan istinsahlarda bazı yazma ve taş baskı nüshalara ekleme ve çıkarmalar yapıldığı görülmektedir. ${ }^{10}$ Nüshalardan kimileri de müellifi bilinmeyecek derecede bir ya da birkaç bölüm hâlinde değişik yazmalar

\footnotetext{
${ }^{7}$ Nüshalar hakkında "XV. Yüzyılda Muhammed Tarafından Yazılan Manzum Sîret'in Nüshaları-I" makalemizde genel bilgiler verdik (Esir, 2019, S I, s. 63-88).

${ }^{8}$ Nüshaların tespitinde Doktora Öğrencim Yavuz Kılıç'ın yardımlarını gördüm. Kendisine teşekkür ederim.

9 “Nâzım-1 Merhûmun Tazarruudur" başlığı 1331 / 1912 tarihli taş baskıda 345. sayfada bulunmaktadır.

${ }^{10} \mathrm{Bu}$ konuda ayrı bir çalışma yapılacaktır.
} 
arasında bulunmaktadırlar. Bunlardan bazıları ayrı eserlermiş gibi kütüphane kayıtlarına girmiştir. Nüshaların hemen tamamı tamir görmüştür. Tamiratta kimi nüshalarda sayfalar birbirine karıştırılmıştır. Sayfalar genellikle önce Arap rakamlarıyla sonra günümüz rakamlarıyla numaralandırılmıştır. Numaralandırmalarda eksikler dikkate alınmamış / fark edilmemiştir. Altı nüshanın metinlerine ulaşılamamıştır; bu nüshaların katalog bilgileri ile yetinilmiştir. Diğer altmış dört nüshadan kırk beşinde yazı nesih, dört nüshada nesih kırması, üç nüshada nesih / nesih kırması, beş nüshada talik, iki nüshada nestalik, iki nüshada rika, üç nüshada nesih / yer yer taliktir. Sîret'in yurt içinde tespit edilen altmış bir yazması on beş farklı yerde bulunmaktadır. Yurt dışında da Bosna-Hersek ve Macaristan'da birer, Almanya'da üç nüshası tespit edilmiştir. Yurt içinde üç kütüphanede dört taş baskı nüsha elde edilmiştir.

Nüshaların pek çoğunda yazılı olan müstensih adı ve istinsah tarihi ile kayıtlardaki bu tarihler arasında eksikler ve yanlışlar bulunmaktadır. Nüshalardan on yedisi hakkında kayıtlarda eser adı dışında hiçbir bilgi yoktur. Bir nüshada da (06 Mil Yz A 5428) her bölümün sonunda istinsah tarihi bulunmaktadır. On üç nüshada (Atatürk Kitaplığ Demirbaş MC_Yz_O_0053, İstanbul Üniversitesi Nadir Eserler TY No: 1601, Konya Mevlana Müzesi Yazmaları No: 1169, Süleymaniye Kütüphanesi Mehmed Zeki Pakalın No: 154, Topkapı Sarayı Müzesi Hazine Kitaplığı 2287 H. 233, Türkiye Yazma Eserler Kurumu Başkanlığı 06 Mil Yz B 1073, Aynı Kütüphane 06 Mil Yz B 360, Aynı Kütüphane 19 Hk 1122, Millet Kütüphanesi Ali Emiri Efendi Manzum 1398, Gazi Husrev-Begova Biblioteka u Sarajevu, No: 4613, Macar Bilimler Akademisi Kütüphanesi Torok Ms F 045, Staatsbibliothek, Berlin Ms.or.fol.3333, Aynı Kütüphane Ms.or.quart.1550) müellifin adı nüsha metinlerinde Muhammed olarak geçmektedir. Bunlardan ancak Konya Mevlana Müzesi Yazmaları No: 1169 ile Macar Bilimler Akademisi Kütüphanesi Torok Ms F 045'teki nüshada müellif doğru olarak kayıtlara geçirilmiştir. Süleymaniye Kütüphanesi Mehmed Zeki Pakalın No: 154'te "Velî, Muhammed"; TYEKB 06 Mil Yz B 360'da "Mehmed Halîfe"; Millet Kütüphanesi Ali Emiri Efendi Manzum 1398'de "Niyâzî"; Gazi Husrev-Begova Biblioteka u Sarajevu No: 4613'te "Mehmed"; Staatsbibliothek Berlin Ms.or.fol.3333 ve Staatsbibliothek Berlin Ms.or.quart.1550'de "Mehmed (Muhammed)" şeklinde tespit edilmiştir. Süleymaniye Kütüphanesi Yazma Bağışlar No: 3916'daki nüshada 1a sayfada kenarda sonradan ve farklı yazı ile "Siyerü'n-Nebî Abdurrahman" notu düşülmüş ve müellifin Abdurrahman olduğu kastedilmiştir. Ayn bilgi, eserin kayıtlı olduğu yerde de mevcuttur. Topkapı Sarayı Müzesi Hazine Kitaplığı 2287 H. 233'te ise "müellifi bulunmayan bir manzum siyer tercümesi" notu düşülmüştür. Diğerlerinde ise müellif yeri boş bırakılmıştır.

Sîret'in müellifi kayıtlarda "Kâdî Asker Şerîf Mehmed Mollâ Efendî"; "Mehmed"; "Sâdık bin Ahmed"; "Muhammed bin Mustafa Hafızi"; "Muhammed Halîfe"; "Mehmed Halîfe"; "Yazıcızade Muhammed Efendi"; "Derviş Öksüz"; "Abdullah Zahidî"; "Velî, Muhammed"; "Abdurrahman"; "Âşıı̂̀"; "Mollâ Velî Efendî”; "Za'ifî̀"; "İsmail Zühdî"; "Za'ifî Pîr Mehmed bin Evrânôs bin Nûreddîn bin el-Fâris"; "Darîr Mustafa bin Ömer Erzûrûmı̂"; "Darîr Mustafa bin Yûsuf Erzûrûmî"; "Veys bin Mustafa"; "Hasanoğlu"ve "Niyâzı̂" gibi yirmi bir farklı şekilde geçmektedir. Taş baskılarda bazı yazmalarda bulunan müellif adı ve eserin telif tarihi çıkarılarak eserin ortalarında bir bölüm eklenmiş, yazar adı "Abdurrahman" olarak değiştirilmiştir. 
Müstensihler için de durum farksızdır. Yetmiş nüshanın yirmi beşinde müstensih adı bulunmaktadır. Müstensih adlarından bazıları bulundukları yerlerdeki kayıtlarda yer almazken bazıları ya eksik ya da yanlıştır. 06 Mil Yz A 2886/2 ve 3'te kayıtlı iki bölümde müstensih "Alâiyyeli Mehmed Efendi", kayitlarda yoktur. 06 Mil Yz A 9814'te müstensih "Pâşâ Ağa bin Seyyid Kâsım Ağa", ilgili yerdeki kayıtta "Kâsım Bedrî"; Atatürk Kitaplığ1 Demirbaş BEL_Yz_O_0073'te müstensih “Seyyid Bekir ibn Süleyman”, ilgili yerdeki kayıtta "Bekir bin Süleyman"; Atatürk Kitaplığı Demirbaş Bel_Yz_K_0489_01'de "Hâfız Muhammed ibn Mustafa", ilgili yerde "Hafızi, Muhammed bin Mustafa: müellif hattı" şeklinde müstensih yanlışlıkla müellif olarak kaydedilmiştir. Konya Bölge Yazma Eserler Ktp. BY 7876' da kayıtlı nüshanın müstensihi "Halîl ibn Ahmed", kayıtlarda yoktur. Konya Koyunoğlu Müze ve Kütüphanesi Arşiv No: 11933’te kayıtlı nüshanın müstensihi “Monla Muhammed ibn İbrahim", kütüphane kaydında "Muhammed bin İbrahim"; Ayn kütüphane Arşiv No: 13278 'de kayıtlı nüshanın müstensihi "Bolulu es-Seyyid İsmail elLafzî", kayıtlarda "İsmail el-Vasfi" şeklindedir. Süleymaniye Kütüphanesi Yazma Bağışlar No: 3378' de kayıtlı nüshada müstensih "Muhammed bin Murâd", aynı kütüphane aynı bölüm 4332' de kayıtlı nüshada müstensih "Muhammed bin İbrahim"dir. Bu iki eserin bulunduğu kütüphane kayıtlarında müellif / yazarlarının"11 "Velî, Muhammed" olduğu not edilmiş. Topkapı Sarayı Müzesi Hazine Kitaplığı 2287 H. 233'te kayıtlı nüshanın müstensihi "Hasan", kayıtlarda yoktur. 06 Mil Yz A 3062'deki nüshada müstensih "İsmail Zühdî”, kayıt bilgilerinde müellif / yazar olarak gösterilmiştir. 06 Mil Yz A 5428'de kayıtlı nüshanın müstensihi "Başmakçılı Hâfız Hüseyin-zâde", kayıtlarda yoktur. 06 Mil Yz A 6547' de kayıtlı nüshanın müstensihi "Veys ibn Mustafa Beg" yazar / müstensih olarak "Veys bin Mustafa" şeklinde kayıtlara geçirilmiştir. 06 Mil Yz B 360' da kayıtlı nüshada müstensih "Muhammed bin Hasan bin Mahmud", kayıtta "Muhammed bin Hasan" şeklindedir. 06 Mil Yz B 310'da kayıtlı nüshada müstensih "Hâfız Osman", kayıtlarda "Seyyid Hafız Osman" şeklindedir. 06 Mil Yz B 370'te kayıtlı nüshada müstensih "Mustafa", kayıtta "Mustafa Hanif" şeklindedir. 06 Mil Yz B 37/1'de kayıtlı nüshada müstensih "Hâfız Hasan bin Abdurrahman", kayıtta "Hasan bin Abdurrahman" şeklindedir. 19 Hk 1122'deki nüshada müstensih "Figânî-zâde Çorumlu Abdullâh bin Mahmûd bin Ebû Bekr", kayıtlarda "Figanî-zade Abdullah bin Mahmûd bin Bekir" şeklindedir. Yazmalardan dördünde müstensih isimleri "sâhip ve mâliki" ifadesi altında geçmektedir. Bir yazmada (Sermet Çifter Araştırma Kütüphanesi TY No: 823) "sâhip ve mâliki" ifadesinden sonra gelen ismin yazmanın sahibi mi müstensihi mi olduğu açık değildir. Bir yazmada (DTCF Kütüphanesi Muzaffer Ozak I 50) ikinci bir sahiplik kaydı ve sahiplik tarihi bulunmaktadır. Ayrıca bir tamir (Konya Bölge Yazma Eserler Kütüphanesi BY 7876), bir de vakıf (06 Mil Yz A 7167) kaydıvardır. Bunların da hiçbiri eserlerin bulundukları kütüphanelerdeki kayıtlara geçirilmemiştir. Taş baskı nüshalarda da durum bundan farksızdır. Taş baskılarda Edirne Selimiye Kütüphanesi 22 Sel 2532'te kayıtlı nüshanın yazarı "Abdurrahman" şeklindedir. İrcica Kütüphanesi 297.63.MU.S'te kayıtlı iki nüshada da yazar "Mustafa Nazif Kadırgavi" olarak kayıtlanmıştır. Atatürk Kitaplığı Demirbaş No: DA_0178'de kayıtlı taş baskıda yazar adı belirtilmemiştir. Eserin taş baskılarında da yazma nüshaların çoğunda olduğu gibi Muhammed'in Sîret'i apayrı bir eser olmuştur.

Kütüphanelerdeki kayıtlarda Siret'in telif, istinsah, kütüphane ve taş bask1 tarihlerinde de eksikler ve yanlışlar bulunmaktadır. 06 Mil Yz A 2886/2 ve 3, 06 Mil Yz A

11 Kütüphanelerdeki kayıtlarda "yazar" ifadesinin müellif karşılı̆̆ı kullanıldığı anlaşılıyor. 
9814, Atatürk Üniversitesi Merkez Kütüphanesi Seyfettin Özege No 234 SA, Konya Bölge Yazma Eserler Kütüphanesi BY 7876, Konya Koyunoğlu Müze ve Kütüphanesi Arşiv No: 11893, Konya Mevlana Müzesi Yazmaları No: 1169, Süleymaniye Kütüphanesi Yazma Bağışlar, No: 3378 ve 4332, Türkiye Yazma Eserler Kurumu Başkanlığı 06 Mil Yz A 2839, ayn Kurum 06 Mil Yz A 9105/3 ve 4'te kayıtlı yazmalardaki istinsah tarihleri nüshaların bulundukları yerlerdeki kayıtlara geçirilmemiştir. Konya Koyunoğlu Müze ve Kütüphanesi Arşiv No: 11933, Türkiye Yazma Eserler Kurumu Başkanlı̆̆ 06 Mil Yz A 6547'de kayıtlı nüshalardaki istinsah tarihleri ile nüshaların ait oldukları yerlerdeki istinsah tarihleri birbirinden farklıdır. Türkiye Yazma Eserler Kurumu Başkanlığı 06 Mil Yz A 5428'deki yazmada iki, aynı Kurum 55 Hk 458/11'deki yazmada dört ayrı istinsah kaydı mevcuttur. Otuz dört nüshada ne yazmalarda ne de kayıtlarda istinsah tarihleri bulunmaktadır. Bir nüshada yazmadaki istinsah tarihinden başka tamir tarihi, bir nüshada ikinci kez istinsah tarihi, bir nüshada yazmada sahiplik tarihi ve (yazmada olmayıp) kütüphane kaydında muhtemel istinsah tarihi vardır. Nüshalardan sekizinin metninde eserin telif tarihi bulunmaktadır. Bunlardan ancak dört tanesi fark edilip yazmaların ait oldukları yerlerdeki kayıtlara geçirilmiştir. Sîret'in Staatsbibliothek, Berlin, Ms.or.quart.1550'de kayıtlı Kıssa-i Nikâh-1 Hazret-i Hadîce nüshasının telif tarihinin 872 [1467] olduğu Hanna Sohrweide Türkische Handschriften adlı eserinde belirtmiştir (Sohrweide, 1981, Vol. 5, s. 223). Nüshaların ancak on yedisindeki istinsah tarihleri ile bu nüshaların kayıtlı oldukları yerlerdeki istinsah tarihleri aynidır.

\section{Sîret' in Adı ve Müellif / Müstensih Kayıtlarındaki Hatalar ve Sebepleri}

Sîret'in Siyer-i Nebi, Sîretü'n-Nebî, Terceme-i Siyer-i Nebi, Siyer-i Nebî Tercemesi, Siyer-i Nebiye Aid Bir Manzume gibi içinde sîret / siyer ifadesi bulunan kayıtları bir kabul edilirse; Kıssa-i Alî, Kitabu Haticeti'l-Kübra Destanı, Hikaye-i Nikâh El-Mustafa Bi Hadice, Kıssa-i Nikâh-ı Hazret-i Hadîce, Manzûme-i Hatîcetü'l-Kübrâ, Dasitan-ı Mustafa, Gazavât-ı Hz. Alî, Gazavât-nâme, Gazavât-ı Nebî (Siyer-i Nebî), Menâkıb-name, Cenk-nâme, Ceng-nâme-i Hz. Alî, Menâkıb-ı Hazret-i Alî, Kısas-ı Sülehâ ve Urefâ, gibi on dört farklı adla kaydedildiği görülmektedir. Ayrıca $06 \mathrm{Mil}$ Yz A 2886/2'de Kıssa-i Hayber, 06 Mil Yz A 2886/3'te Kıssa-i Mikdad İbn Esved, TYEKB 06 Mil Yz A 9105/3'te Gazâ-i Benî Kureyze, TYEKB 06 Mil Yz A 9105/4'te Kıssa-i Hazret-i Ömer ve Staatsbibliothek, Berlin, Ms.or.oct.2083'te Dâsitân-ı Gazavât-ı Resûl As. Alâ Kal'at-ı Mecûsiyân, Dâsitân-ı İslâm-ı Hazret-i Ömer, Dâsitân-ı Gazavât-ı Resûlüllâh, Dâsitân-ı Abdurrahmân bin Ebî Bekr, Kıssa-i Nikâh-ı Hazret-i Hadîce farklı eserler gibi algılansa da Sîret'in bölümleridir. Bunlar da eklendiğinde sayı yirmi iki olmaktadır. Sîret'in bu kadar farklı kaydedilmelerinin sebepleri nelerdir?

\section{Sîret'in Ad1}

Sîret'in bazı bölüm / bölümleri kütüphanelerde ya müstakil ya da yazmalar arasındadır. Sîret'in adı bilhassa eksik nüshalarda farklı şekillerde kayıtlara geçirilmiştir. Mesela 06 Mil Yz A 8940'ta Ceng-nâme-i Hz. Alî, 06 Mil Yz B 37/1'de Gazavât-nâme, Millet Kütüphanesi Ali Emiri Efendi Manzum 1398'de Gazavât-ı Neb̂̂ (Siyer-i Neb̂̂), 06 Mil Yz A 7004'te Menâkıb-nâme, 06 Mil Yz A 3115'te Kısas-ı Sülehâ' ve Urefấ: 06 Mil Yz A 2763/2'de Menâkıb-ı Hazret-i 'Alî, 06 Mil Yz A 8631/2'de Manzûme-i Hatîcetü'l-Kübrâ gibi. Bu adlandırmaların muhtevadan hareketle yapıldığı söylenebilir. Türkiye Yazma Eserler Kurumu Başkanlığı Arşiv No: 06 Mil Yz A 3822'de Kıssa-i Siyer-i Nebi adıyla kayıtlı nüshanın Sîret olduğu 1a yedinci beyit "Sîretini ol kerîm Peygamberin" mısrasındaki "sîretini" kelimesinin altı kırmızı ile çizilerek tespit edilmiştir. Millet Kütüphanesi Ali Emiri Efendi

SEFAD, 2019; (42): 107-130 
Manzum 1398'de Gazavât-ı Nebî (Siyer-i Nebî̀)12 adıyla kayıtlı nüsha 1a'da "Siyer-i Nebî noksandır." notu düşülerek nüshanın Sîret olduğu belirtilmiştir. Sîret'in bazı eksik nüshaları ve yazma nüshalar içinde bulunan bölüm / bölümleri başlık adlarıyla kaydedilmiştir. 06 Mil Yz A 9105/3'te Gazâ-i Benî Kureyze, Arşiv No: 06 Mil Yz A 9105/4'te Kissa-i Hazret-i Ömer. 06 Mil Yz A 2886/2'de Kıssa-i Hayber ve 06 Mil Yz A 2886/3'te Kıssa-i Mikdad İbn Esved buna örnektir.

\section{Sîret' in Müellif / Müstensih Tespitlerinde Hatalar ve Sebepleri}

Türkiye Yazma Eserler Kurumu Başkanlığı 06 Mil Yz B 310'da kayıtlı nüshanın yazarı / müellifi Mehmed Halîfe olarak tespit edilmiştir. Bu ismin, eserin $341^{b}$ dördüncü beyitte geçen Halîfe ve diğer bazı nüshalarda bulunan ve müellifin adı olan Muhammed'din bir araya getirilerek oluşturulduğu söylenebilir. Her ne kadar Muhammed ve Halîfe isimleri Türkiye Yazma Eserler Kurumu Başkanlığı 06 Mil Yz B 360, 370 ve 453; Konya Bölge Yazma Eserler Kütüphanesi BY 7876'da kayıtlı nüsha metinlerinde geçmese de (bu nüshalar eksiktir) yine bu nüshaların ilgili yerlerdeki müellif / yazarları da Mehmed Halîfe (BY 7876'de Muhammed Halîfe) olarak kaydedilmiştir.

Türkiye Yazma Eserler Kurumu Başkanlığı 05 Ba 1460'ta kayıtlı Manzûm Siyer-i

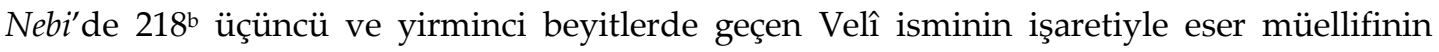
kütüphane kayıtlarına Molla Velî Efendi şeklinde geçirildiği anlaşılıyor. Eserin telif tarihinin $218^{\text {b }}$ beşinci beyitte geçmesi dolayısıyla da kütüphane kayıtlarında "yazar Mollâ Velî Efendi'nin 872'de [1467] sağ olduğu" notu düşülmüştür. Halîfe ve Velî isimleri Sîret'in MC_Yz_O_0053'te kayıtlı ve tespit edilen nüshalar arasında istinsahı bilinen en eski nüshada 491 dördüncü, 492a dokuzuncu ve 494 birinci beyitlerde geçmektedir. Bu isimler Sîret'in müellifi değil müstensihleridir. Süleymaniye Kütüphanesi Mehmed Zeki Pakalın, No: 154, Aynı Kütüphane Yazma Bağışlar No: 3378 ve 4332'de kayıtlı nüshaların müellifi de "Velî, Muhammed" olarak iki kişi anlaşılacak şekilde kaydedilmiştir. Muhammed, eserin müellifidir, Velî ise müstensihtir. Bu kayıttan müellifin tam olarak tespit edilemediği anlaşllyyor.

Türkiye Yazma Eserler Kurumu Başkanlığı 06 Mil Yz A 2839, 06 Mil Yz A 3115, 06 Mil Yz A 3822, 06 Mil Yz A 3823, 06 Mil Yz A 3824'te kayıtlı nüshaların yazarı Za'ifî (Za'ifî Pîr Mehmed bin Evrânôs bin Nûreddîn bin el-Fâris) (öl. 1557) olarak tespit edilmiştir. Bu nüshalar oldukça eksiktir. Bugünkü bilgimizle Za'ifî́nin Siyer'i yoktur. Bu yanlış tespit acaba 06 Mil Yz A 3822'de kayıtlı nüshada 20 yedinci beyitte "İ ulu ben za'if pîrem didüm" mısrasındaki "za'if" kelimesine bakılarak yapıldı da diğer dört kayda bu yolla mı geçti? Eğer böyle olduysa buradaki "za'îf" kelimesinin isim olmadığı açıktır. Yoksa Za'îfî'nin eserlerinden yola çıkılarak Sîret'i de olabileceği hükmüne mi varıldı? Yine Türkiye Yazma Eserler Kurumu Başkanlığı 06 Mil Yz A 5428, 06 Mil Yz A 8471 ve 06 Mil Yz B 274'de kayıtlı nüshaların yazarları / müellifleri de Darîr Mustafa bin Ömer Erzurumî (Darîr Mustafa bin Yûsuf Erzurumî) olarak kayıtlıdır. Söz konusu yanlışlı̆ıı Darîr'in (XIV. yy.) Sîretü'nNebî'siyle karıştırılmasından kaynaklandığı ilk akla gelen sebeptir. Konya Koyunoğlu Müze ve Kütüphanesi Arşiv No: 11411'de kayıtlı nüsha hicri H 855'te [1451] vefat eden ve daha ziyade Muhammediye'si ile tanınan Yazıcığlu Muhammed adına kayıtlıdır. Nüsha fiziksel olarak tam olsa da konu bakımından eksiktir ve müellif adının geçtiği bölümler nüshada

12 Kütüphane yetkilileriyle görüştüğümüzde Tespit Fişinde Gazavât-ı Neb̂̂ (Siyer-i Neb̂̂) şeklinde kayıtlı olan eserin adının Siyer-i Nebî olarak değiştirileceği söylendi. 
yoktur. Yazıcıoğlu'nun siyer konusundaki Muhammediye'si ile konu benzerliği dolayısıyla bu yanlışlığın yapıldığı söylenebilir.

Süleymaniye Kütüphanesi Mehmed Zeki Pakalın, No: 154'te Siyer-i Nebi (Manzum) nüshası 403a ikinci beyit "Bu Muhammed hakkına kim bir du'â" misrasında geçen "Muhammed hakkına" ibaresinin altı kırmızı ile çizilerek yanlış olarak eserin müellifinin "Muhammed Hakkı" olduğuna hükmedilmiştir. Benzer şekilde Konya Koyunoğlu Müze ve Kütüphanesi, Arşiv No: 11893'te kayıtlı Siret-i Nebi 11b ilk mısra "Her ki varsa dervîş öksüz yâ esîr" deki "dervîş öksüz" ibaresinin altı siyah ile çizilerek eser müellifinin "Dervîş Öksüz" olduğuna hükmedilmiştir. Yine Türk Dil Kurumu Yazmaları Yz.A.338'de kayıtlı Siyer-i Nebî' de 96 bon beyit ilk mısra "'Âşıkı 'sşka kalem sen çek tamâm” daki "'Âşıkı" kelimesinin altı kırmızı ile çizilerek eser müellifinin "Âşıkî" olduğuna hükmedilmiştir.

Türkiye Yazma Eserler Kurumu Başkanlığı Arşiv No 06 Mil Yz B 370'de Siretü'n-Nebi olarak kayıtlı nüshada 181'b'de müstensih Mustafa, "'an-yedi 'abdi'z-za'îfi'n-nahîf..." ibaresinde "ez-za'îf en-nahîf" kelimeleri arasında bâ-Mustafâ" biçiminde yazılmıştır. Nüsha kaydını çıkaranların "nahîf"i "hanîf" okuyarak müstensihi "Mustafa Hanîf" şeklinde tespit ettikleri anlaş1lyyor.

Atatürk Kitaplığı Demirbaş Bel_Yz_K_0489_01'deki nüshanın müellifi kütüphane kayıtlarında "Hâfız Muhammed ibn Mustafa" olarak geçmektedir. Nüshanın 288a yaprağında geçen bu isim yazmanın müstensihidir. Bu yanlışlık aynı kütüphane Demirbaş BEL_Yz_O_0073'te kayıtlı nüshanın müellif tespitinde de tekrar edilmiştir. Köprülü Kitaplığı Hacı Ahmed Paşa, No: 234'teki Siyer-i Nebî konu bakımından oldukça eksik bir nüshadır. Nüshada müellif ya da müstensihe dair bilgisi yoktur. Nüshanın bulunduğu Kütüphanede müellifi "Abdullah Zahidi Efendi" olarak kayıtlıdır. Ancak eserde bu isim yoktur. Neye dayanılarak bu ismin verildiği tespit edilememiştir. Dil ve Tarih-Coğrafya Fakültesi Kütüphanesi Muzaffer Ozak I 50'de Siyer (Manzûm) Katalog Fişinde "Sâdık bin Ahmed" adına kaydedilmiştir. "Sâdık bin Ahmed" adı nüshada bulunmamaktadır. Bu ismin neye dayanılarak verildiği de tespit edilememiştir.

Süleymaniye Kütüphanesi Yazma Bağışlar No: 3916'da kayıtlı nüsha oldukça eksiktir. Nüshada 1a kenarda farklı yazı ile "Siyerü'n-Nebî Abdurrahman" notu düşülerek eser müellifinin "Abdurrahman" olduğu belirtilmek istenmiştir. Bu yanlışlık, taş baskılara müellif olarak eklenen Abdurrahman isminden ileri geliyor olabilir. Türkiye Yazma Eserler Kurumu Başkanlığı Arşiv No 06 Mil Yz B 37/1'de Gazavât-nâme adıyla kayıtlı Sîret'in yazarı da ilgili yerdeki kayıtta Abdurrahman'dır. Bu yanlışlık, Süleymaniye Kütüphanesi Yazma Bağışlar No: 3916'da kayıtlı nüshadan kaynaklanabileceği gibi nüshanın $218^{\text {b }}$ varağında bulunan ve müstensih adı olan "Hâfız Hasan bin Abdurrahman"ın kısaltılarak "Abdurrahman" şeklinde müellif adı olarak kayda geçirilmesinden de kaynaklanıor olabilir.

Türkiye Yazma Eserler Kurumu Başkanlığı 06 Mil Yz A 3062 ve 06 Mil Yz A 6547'de kayıtlı nüshaların yazarları / müellifleri olarak gösterilen "İsmail Zühdî" ve "Veys bin Mustafa" nüshaların müellifleri değil müstensihleridir.

Millet Kütüphanesi Ali Emiri Efendi Manzum 1398'de kayıtlı nüsha oldukça eksiktir. Nüshanın 63b3. beyit ikinci mısrası "Rahmet umaram Niyâzî rû-siyâh" şeklinde okunarak 1a yaprakta sonda "Nâzımının ismi Niyâzî'dir. 959 [1551] senesinde telif etmişdir." notu düşülmüş ve müellifinin Niyâzî olduğuna hükmedilmiştir. Bu mısra asıl nüsha ile 
karşılaştıııldığında (63니) yazımında bir yanlışlık görünmemektedir. Mısranın diğer bazı varyantları; İstanbul Büyükşehir Belediyesi Atatürk Kitaplığı Demirbaş MC_Yz_O_0053'teki nüshada "Rahmet umaram yine zî rû-siyâh (492b/9)", Staatsbibliothek Berlin Ms.or.fol.3333'teki nüshada "Rahmet umaram zî rû-yı siyâh (419a/2)", Türkiye Yazma Eserler Kurumu Başkanlığ Arşiv No: 06 Mil Yz B 360'taki nüshada "Yine rahmet umaram hem rû-siyâh (416a/18)", Gazi Husrev-Begova Biblioteka u Sarajevu No: 4613'te ve İstanbul Üniversitesi Nadir Eserler Kütüphanesi TY No 1601'deki nüshalarda“ Rahmet umaram yine ben rû-siyâh (399a/16 // 418a/2)" şeklindedir. Söylendiği gibi, bu kelime "Niyâzî" şeklinde isim olmaktan uzak görünüyor, ayrıca metinde hakkında daha başka en ufak bir bilgi verilmiyor. İsim olsa bile müellif değil müstensihtir. Nüshanın istinsahını yapan "yine zî̀”yi "niyâzı" şeklinde yorumlamış / değiştirmiş olabilir.

İrcica Kütüphanesi 297.63.MU.S'daki taş baskı nüshalardan 1332 tarihli olanın sonunda ketebe kaydında "el-Fakîr e's-Seyyid Mustafa Nazîf e'ş-şehîr bi-Kadirgavî" isminden hareketle yazarının "Mustafa Nazif Kadırgavi" olduğu bilgisi kütüphane kayıtlarına geçirilmiştir. Aynı yanlış bilgi aynı yerdeki diğer nüsha kaydında da tekrar etmiştir.

\section{SONUÇ}

Sîret'in bu kadar çok eksik ve yanlış kayıtları konu üzerinde yapılan çalışmalarda bazı yanlışlara sebep olmuştur. ${ }^{13}$ Bu çalışmada kayıtların eksik ve yanlışlarının ortaya çıarılması ve doğrularının tespiti amaçlanmıştır. Böylece nüshalar farklı eserler zannedilerek bundan sonraki çalışmalarda yapılabilecek muhtemel yanlışlar da önlenmiş olacaktır. Bu çalışma ile kütüphanelerdeki yazma ve basma eser kayıtlarının yeni baştan gözden geçirilmesi gerektiği sonucuna varılmıştır. Sîret'in tespit edilen nüsha kayıtları ekteki tabloda gösterilmiştir.

\section{SUMMARY}

"Sîret" is the opposite of "sûret", which has the meaning of a person's morality, character, and behaviour. "Siyer", which is the plural form of "siret", lexically means styles, means, and aspects. "Megâzî", which is the plural form of the words "mağzâ" and "mağzât" meaning war is the name of the books about the Prophet' holy wars and series and has been used as the synonym of siyer.

First siyer books belong to Arab writers. However, first siyer books in Turkish literature were translations. First Turkish siyer book is Sîretü'n-nebî written in verse and prose by Darîr in the second half of the 14th century. To our present knowledge, first Turkish siyer, which was completely written in verse, is Siret whose copies are evaluated in the present study and which was written by a writer named Muhammad in the $15^{\text {th }}$ century. The work is based on narrations. Five of these narrations belong to Ebü'l-Hasan Bekrî (DOD VII. / XIII. yy.?). In addition, there are narrations whose owner is not known in the work.

The writer of Siret is someone called Muhammad. He has not been mentioned in literature. However, it is possible to find little information about him in some verses of Siret.

\footnotetext{
${ }_{13}$ Nitekim bu çalışmayı yaptığımızda Türkiye Yazma Eserler Kurumu Başkanlığı 06 Mil Yz A 2630/2, 06 Mil Yz A 2763/2, 06 Mil Yz A 3941, 06 Mil Yz A 6712, 06 Mil Yz A 7004, 06 Mil Yz A 7167, 06 Mil Yz A 8631/2, 06 Mil Yz A 8778, 06 Mil Yz A 8940, 06 Mil Yz A 8902, 06 Mil Yz A 9105/3, 06 Mil Yz A 9105/4, 06 Mil Yz B 1073'teki nüshaların dijital ortamdaki kayıtlarında Yazar Adı yeri boştu. Bu alana daha sonra "Kâdî Asker Şerîf Mehmed Mollâ Efendî (öl. 1308/1890)" eklenmiştir. Yazar Adı olarak bu ad yanlıştır.
} 
The writer stated his name as Muhammad at the beginning and at the end of Siret and the name of the work as Siret.

He explained that he was not a poet, but he knew the particulars of poetry. He created his work to narrate the Prophet's miracles and to praise him. He did not intend to write a poem, but he was filled with enthusiasm and started to write Siret. He wrote his work in Turkish and completed it in the Friday morning of Rebiü'l-evvel (Rebiü'l-âhirin Berlin copy) in 872/1467 according to the Muslim calendar. He might have died at that date at the earliest as he completed his work in $872 / 1467$.

There is different information about the name, writer and copyist of Siret especially in uncomplete copies in library records. This leads to confusion and wrong determination on the work in some studies. It is remarkable that these mistakes are often repetition of each other.

The fact that there were various written and stone print copies of Siret from the $15^{\text {th }}$ century when it was written to the beginning of the $20^{\text {th }}$ century shows that it was loved and read too much. Many copies were damaged. It can be said that this damage was because the copies changed hands many times and were read by many people. Besides, pages and chapters were confused in some copies. Especially beginning and last parts of manuscripts were exposed to damage. Almost all of the copies were numbered without considering deficiencies and disorders.

Those who copied Siret and created its stone print could not desist from making addition to the work and adopting it. For example, there is not the name of the writer, Muhammad, in any stone prints. Instead, the writer of the work was changed as Abrurrahman and some verses were added under the heading "Nâzım-1 Merhûmun Tazarruudur"at the page of 361 (at the page of 345 on the stone print dated 1331/1912). The writer's name was also changed in some written copies.

Some written copies of Siret are placed among different manuscripts, which makes the writer unknown. Some of them are found in library records as if they were the same. There are mistakes and differences between the copyist's name and copy date written on many manuscripts and the dates on the records. Consequently, the name of the work and the writer's name have been recorded in twenty-one and nineteen different ways, respectively. Incomplete and wrong records of Siret have caused mistakes in the studies conducted on the subject.

In the present study, the aim is to introduce and evaluate the manuscripts of Siret. Thus, it is intended to prevent people from thinking that the copies belong to different works. 


\section{KAYNAKÇA}

Can, A. (2014). Muhammed'in Sîretü'n-Nebî'si (1-3422. beyit) (inceleme-metin) (Yayımlanmamış yüksek lisans tezi). Diyarbakır: Dicle Üniversitesi. Erişim adresi: https://tez.yok.gov.tr/UlusalTezMerkezi/tezSorguSonucYeni.jsp

Can, A. (2015). Muhammed'in Siret'ün-Nebî'sindeki mi'râç mucizesi bölümü üzerine. Turkish StudiesInternational Periodical For The Languages Literature and History of Turkish or Turkic, Volume 10/4 Winter, s. 257-318. DOI Number: http://dx.doi.org/10.7827/TurkishStudies.7955

Çelebioğlu, Â. (1996). Muhammediye. Cilt 1. İstanbul: Millî Eğitim Bakanlığı Yayınları.

el-Shaman, Massad Süveylim Ali (1982). Türk edebiyatında siyerler ve İbn Hişam'ın Siyer'inin Türkçe tercümesi (yayımlanmamış doktora tezi). Cilt 1. Ankara: Ankara Üniversitesi.

Esir, H. A. (2019). XV. yüzyılda Muhammed tarafından yazılan manzum Sîret'in nüshaları-I. Selçuk Üniversitesi Edebiyat Fakültesi Dergis, 1, 63-88. Erişim adresi: http://sefad.selcuk.edu.tr/sefad/issue/view/45/showToc

Fayda, M. (2009). Siyer ve megâzî. Türkiye Diyanet Vakfi İslam Ansiklopedisi. Cilt 37. s. 319-324. İstanbul: Türkiye Diyanet Vakfı Yayınları.

Kaplan, Y. (2006). Erzurumlu Kadı Mustafa Darîr'in Kitâb-ı Siyer-i Nebî'si (Yayımlanmamış yüksek lisans tezi). Ankara: Ankara Üniversitesi. Ereşim adresi: https://tez.yok.gov.tr/UlusalTezMerkezi/tezSorguSonucYeni.jsp

Kavruk, H. ve Kadığlu, İ. (2017). Manzum siyer-i nebî. Malatya: İnönü Üniversitesi Yayınları.

Kocatürk, V. M. (1970). Türk edebiyatı tarihi. Ankara: Edebiyat Yayınevi.

Köksal, F. (2011). Mevlid-nâme. Ankara: Türkiye Diyanet Vakfı Yayınları.

Köse, F. (2017). Yazar bilinmeyen bir Hz. Hatice hikâyesi (tenkitli metin-inceleme) (Yayımlanmamış yüksek lisans tezi). Ankara: Gazi Üniversitesi. Erişim adresi: https://tez.yok.gov.tr/UlusalTezMerkezi/tezSorguSonucYeni.jsp

Özfırat, B. (2014). Türk edebiyatının manzum ilk siyeri: Velî̀nin Sîretü'n-Nebî'si. Divan Edebiyatı Araştırmaları Dergisi, 12, 93-134. Erişim adresi: https://docplayer.biz.tr/35625765-Turk-edebiyatinin-manzum-ilk-siyeri-veli-nin-siretun-nebi-si.html

Özfırat, B. (2016). 15. yüzyll şairlerinden Muhammed'in Sîretü'n-Nebî'si (Yayımlanmamış doktora tezi). İstanbul: Marmara Üniversitesi. Erişim adresi: https://tez.yok.gov.tr/UlusalTezMerkezi/tezSorguSonucYeni.jsp

Özmen, M. (2011-2012). Za'ifín'nin manzum Siyer-i Nebî'sinin transkripsiyonlu çevirisi ve incelenmesi (Yayımlanmamış yüksek lisans tezi). Ordu: Ordu Üniversitesi. Erişim adresi: https://tez.yok.gov.tr/UlusalTezMerkezi/tezSorguSonucYeni.jsp

Öztoprak, N. (2010). Türk edebiyatında manzum siyerler. B. Kemikli, O. Çetin (Yay. haz.). Yazılışının 600. yılında bir kutlu doğum şaheseri uluslar arası mevlid sempozyumu. 16-17 Nisan 2009 (s. 51-70). Ankara: Türkiye Diyanet Vakfı Yayınları.

Pekolcay, N. (1997). Süleyman Çelebi Mevlid (Vesîletü'n-Necât). Ankara: Türkiye Diyanet Vakfı Yayınları.

Sohrweide, H. (1981). Türkische handschriftenteil V. Wiesbaden: Franz Steiner Verlag Gmbh. Erişim adresi: https://rep.adw-goe.de/handle/11858/00-001S-0000-0023-9B23-D

Türkiye Diyanet Vakfı İslam Ansiklopedisi (1992). Cilt 5. Bekrî, Ebü'l-Hasan el-Kasasî. (s. 366). İstanbul: Türkiye Diyanet Vakfı Yayınları.

Uzun, M. (2009). Türkçe siyer kitapları. Türkiye Diyanet Vakfı İslam Ansiklopedisi. Cilt 37. s. 324-326. İstanbul: Türkiye Diyanet Vakfı Yayınları.

Yılmaz, E. (1995). Gazavâtnâmeler ve Niyâzî̀nin Gazavât-ı Nebî'si (Yayımlanmamış yüksek lisans tezi). İstanbul: Marmara Üniversitesi. Yök erişim izni bulunmamaktadır. 
EK: Sîret'in Tespit Edilen Nüsha Kayıt Tablosu

\begin{tabular}{|c|c|c|c|c|c|}
\hline Sira & $\begin{array}{l}\text { Kütp. Kayıt Yeri } \\
\text { ve No. }\end{array}$ & Eserin Adı & $\begin{array}{l}\text { Nüshada Müellif } \\
\text { / Müstensih / } \\
\text { Sahip Adı }\end{array}$ & $\begin{array}{l}\text { Kütüphane } \\
\text { Kaydında Müellif / } \\
\text { Yazar / Müstensih } \\
\text { Adı }\end{array}$ & $\begin{array}{l}\text { Telif / İstinsah / Temellük / } \\
\text { Taş Baskı / Kütüphane Kayıt } \\
\text { Tarihi }\end{array}$ \\
\hline \multirow{2}{*}{1} & $\begin{array}{l}\text { Ankara Millî Ktp. } \\
06 \text { Mil Yz A 2886/2 }\end{array}$ & Kissa-i Hayber & \multirow[t]{2}{*}{$\begin{array}{l}\text { Müstensih: } \\
\text { Alâiyyeli Mehmed } \\
\text { Efendi }\end{array}$} & \multirow[t]{2}{*}{ Yok } & \multirow[t]{2}{*}{ Yazmada İstinsah: 1262 [1845] } \\
\hline & $\begin{array}{l}\text { Ankara Millî Ktp. } \\
06 \text { Mil Yz A 2886/3 }\end{array}$ & $\begin{array}{l}\text { Kissa-i } \\
\text { Mikdad İbn } \\
\text { Esved }\end{array}$ & & & \\
\hline 2 & $\begin{array}{l}\text { Ankara Millî Ktp. } \\
06 \text { Mil Yz A } 9814\end{array}$ & Kıssa-i Alî & $\begin{array}{l}\text { Müstensih: Pâşâ } \\
\text { Ağa bin Seyyid } \\
\text { Kâsım Ağa }\end{array}$ & $\begin{array}{l}\text { Müstensih: Kâsım } \\
\text { Bedrî }\end{array}$ & Yazmada İstinsah: 1219 [1804] \\
\hline 3 & $\begin{array}{l}\text { AÜ Merkez Ktp. } \\
\text { Seyfettin Özege } \\
\text { No } 234 \text { SA }\end{array}$ & Siretü'n nebi & Yok & Yok & Yazmada İstinsah: 1066 [1655] \\
\hline 4 & $\begin{array}{l}\text { DTCF Ktp. } \\
\text { Mustafa Con A } \\
594\end{array}$ & $\begin{array}{l}\text { [Manzûm } \\
\text { Siyer] (Siyer-i } \\
\text { Nebî) }\end{array}$ & Yok & Yok & Yok \\
\hline 5 & $\begin{array}{l}\text { DTCF Ktp. } \\
\text { Muzaffer Ozak I } \\
50\end{array}$ & $\begin{array}{l}\text { Siyer } \\
\text { (Manzûm) }\end{array}$ & $\begin{array}{l}\text { Sahibi } \\
\text { (Müstensihi): } \\
\text { Hâlid bin Alî bin } \\
\text { Ramazan bin } \\
\text { Heytem (veya } \\
\text { Heyâtim) } \\
\text { İkinci Bir Sâhiplik } \\
\text { Kaydı: Hâlid bin } \\
\text { Alî bin Ramazân } \\
\text { Bâyezîd bin } \\
\text { Ahmed bin Alî bin } \\
\text { Îsâ Ahmed bin Alî } \\
\text { oglı }\end{array}$ & $\begin{array}{l}\text { Katalogda Sâdık bin } \\
\text { Ahmed adına kayıtlı }\end{array}$ & $\begin{array}{l}\text { Yazmada İkinci Sahiplik } \\
\text { Kaydı: } 10 \text { Nisan } 1925 \text { / } 9 \\
\text { Şa'bân } 1345 \\
\text { Diğerleri: Yok }\end{array}$ \\
\hline 6 & $\begin{array}{l}\text { İstanbul BB } \\
\text { Atatürk Kitaplığ1 } \\
\text { Demirbaş } \\
\text { BEL_Yz_O_0073 }\end{array}$ & Siret en-Nebi & $\begin{array}{l}\text { Müstensih: Seyyid } \\
\text { Bekir ibn } \\
\text { Süleyman }\end{array}$ & $\begin{array}{l}\text { Müellif: Muhammed } \\
\text { bin Mustafa Hafızi } \\
\text { Müstensih: Bekir bin } \\
\text { Süleyman }\end{array}$ & Yok \\
\hline 7 & $\begin{array}{l}\text { İstanbul BB } \\
\text { Atatürk Kitaplığ1 } \\
\text { Demirbaş } \\
\text { Bel_Yz_K_0489_01 }\end{array}$ & Siret en-Nebi & $\begin{array}{l}\text { Müstensih: Hâfız } \\
\text { Muhammed ibn } \\
\text { Mustafa }\end{array}$ & $\begin{array}{l}\text { Hafızi, Muhammed } \\
\text { bin Mustafa, Müellif } \\
\text { hattı }\end{array}$ & $\begin{array}{l}\text { Yazmada İstinsah: [1]265 } \\
\text { [1848] } \\
\text { Kütüphane Kaydında İstinsah: } \\
1265 \text { [1848] }\end{array}$ \\
\hline
\end{tabular}




\begin{tabular}{|c|c|c|c|c|c|}
\hline 8 & $\begin{array}{l}\text { İstanbul BB } \\
\text { Atatürk Kitaplığı } \\
\text { Demirbaş } \\
\text { MC_Yz_O_0053 }\end{array}$ & Siret en-Nebi & $\begin{array}{l}\text { Müellif: } \\
\text { Muhammed } \\
\text { Müstensih: } \\
\text { Mustafa bin } \\
\text { Bayezid }\end{array}$ & $\begin{array}{l}\text { Müellif:Muhammed } \\
\text { Müstensih: Mustafa } \\
\text { bin Bayezid }\end{array}$ & $\begin{array}{l}\text { Eserin Telif Y1lı 492a on birinci } \\
\text { beyitte: } 872 \text { [1467] } \\
\text { Yazmada İstinsah: } 939 \text { [1532] } \\
\text { Kütüphane Kaydında İstinsah: } \\
939 \text { [1532] } \\
\text { Kütüphane Kaydında Telif: } \\
872 \text { [1467] }\end{array}$ \\
\hline 9 & $\begin{array}{l}\text { IÜ Nadir Eserler } \\
\text { Ktp. TY No } 1601\end{array}$ & Siretü'n-Nebî & $\begin{array}{l}\text { Müellif: } \\
\text { Muhammed }\end{array}$ & Yok & $\begin{array}{l}\text { Eserin Telif Y1lı } 417^{b} \text { on altınc1 } \\
\text { beyitte: } 872[1467] \\
\text { Diğerleri: Yok }\end{array}$ \\
\hline 10 & $\begin{array}{l}\text { Konya Bölge } \\
\text { Yazma Eserler } \\
\text { Ktp. } 15 \text { Hk } 1499\end{array}$ & Siyer-i Nebî & Yok & Yok & Yok \\
\hline 11 & $\begin{array}{l}\text { Konya Bölge } \\
\text { Yazma Eserler } \\
\text { Ktp. BY } 7876\end{array}$ & Siretü'n-Nebi & $\begin{array}{l}\text { Müstensih: Halîl } \\
\text { ibn Ahmed } \\
\text { Tamir eder: Hâfız } \\
\text { Ahmed ibn } \\
\text { Hüseyin }\end{array}$ & $\begin{array}{l}\text { Yazar: Muhammed } \\
\text { Halîfe }\end{array}$ & $\begin{array}{l}\text { Yazmada İstinsah: } 1250 \text { [1834] } \\
\text { Tamir Tarihi: } 1246 \text { [1830] }\end{array}$ \\
\hline 12 & $\begin{array}{l}\text { Konya Bölge } \\
\text { Yazma Eserler } \\
\text { Ktp. BYEK D NO } \\
3539\end{array}$ & Siretü'n-Nebi & Yok & Yok & Yok \\
\hline 13 & $\begin{array}{l}\text { Konya Koyunoğlu } \\
\text { Müze ve Ktp. } \\
\text { Arşiv No: } 10731\end{array}$ & $\begin{array}{l}\text { Hikaye-i } \\
\text { Nikah El- } \\
\text { Mustafa Bi } \\
\text { Hadice }\end{array}$ & Yok & Yok & Yok \\
\hline 14 & $\begin{array}{l}\text { Konya Koyunoğlu } \\
\text { Müze ve Ktp. } \\
\text { Arşiv No: } 11411\end{array}$ & Siret-i Nebiy & Yok & $\begin{array}{l}\text { Yazar: } \\
\text { Yazıcızade Muham } \\
\text { med Efendi } \\
(\mathrm{V} .855 / \mathrm{H})\end{array}$ & $\begin{array}{l}\text { Yazmada İstinsah: } 1165 \text { [1751] } \\
\text { Kütüphane Kaydında İstinsah: } \\
1165 \text { [1751] }\end{array}$ \\
\hline 15 & $\begin{array}{l}\text { Konya Koyunoğlu } \\
\text { Müze ve Ktp. } \\
\text { Arşiv No: } 11893\end{array}$ & Siret-i Nebi & Yok & $\begin{array}{l}\text { Yazar: Derviş } \\
\text { Öksüz. }\end{array}$ & $\begin{array}{l}\text { Yazmada İstinsah: [1]127 } \\
\text { [1715] }\end{array}$ \\
\hline 16 & $\begin{array}{l}\text { Konya Koyunoğlu } \\
\text { Müze ve Ktp. } \\
\text { Arşiv No: } 11933\end{array}$ & $\begin{array}{l}\text { Kitabu } \\
\text { Haticeti'1- } \\
\text { Kübra Destanı }\end{array}$ & $\begin{array}{l}\text { Müstensih: Monla } \\
\text { Muhammed ibn } \\
\text { İbrahim }\end{array}$ & $\begin{array}{l}\text { Müstensih: } \\
\text { Muhammed bin } \\
\text { İbrahim }\end{array}$ & $\begin{array}{l}\text { Yazmada İstinsah: } 1171 \text { [1757] } \\
\text { Kütüphane Kaydında İstinsah: } \\
0 \text { [1757] }\end{array}$ \\
\hline 17 & $\begin{array}{l}\text { Konya Koyunoğlu } \\
\text { Müze ve Ktp. }\end{array}$ & $\begin{array}{l}\text { Manzum } \\
\text { Siyer-i Nebi }\end{array}$ & $\begin{array}{l}\text { Müstensih: Bolulu } \\
\text { es-Seyyid İsmâîl }\end{array}$ & $\begin{array}{l}\text { Müstensih: İsmail el- } \\
\text { Vasfi }\end{array}$ & $\begin{array}{l}\text { Yazmada İstinsah: [12]62 } \\
{[1845]}\end{array}$ \\
\hline
\end{tabular}


Bahseden Çalışmalar ve Sîret'in Nüsha Kayıtları-II

\begin{tabular}{|c|c|c|c|c|c|}
\hline & Arşiv No: 13278 & & el-Lafzî & & $\begin{array}{l}\text { Kütüphane Kaydında İstinsah: } \\
1262 \text { [1845] }\end{array}$ \\
\hline 18 & $\begin{array}{l}\text { Konya Koyunoğlu } \\
\text { Müze ve Ktp. } \\
\text { Arşiv No: } 13775\end{array}$ & $\begin{array}{l}\text { Dasitan-1 } \\
\text { Mustafa } \\
\text { (S.A.V.) }\end{array}$ & Yok & Yok & Yok \\
\hline 19 & $\begin{array}{l}\text { Konya Mevlana } \\
\text { Müzesi Yazmaları } \\
\text { No: } 1169\end{array}$ & Sîrat'an-Nabi & $\begin{array}{l}\text { Müellif: } \\
\text { Muhammed } \\
\text { Müstensih: Konevî } \\
\text { Abdurrahîm bin } \\
\text { Halîl Hâce }\end{array}$ & $\begin{array}{l}\text { Müellif: Muhammed } \\
\text { Müstensih: Konevî } \\
\text { Abdurrahîm bin } \\
\text { Halîl Hâce }\end{array}$ & $\begin{array}{l}\text { Yazmada İstinsah: } 1181 \text { [1767] } \\
\text { Kütüphane Kaydında Telif: } \\
\text { Hicri IX ya da X. yy. }\end{array}$ \\
\hline 20 & $\begin{array}{l}\text { Köprülü Kitaplığı } \\
\text { Hacı Ahmed Paşa, } \\
\text { No: } 234\end{array}$ & Siyer-i Nebî & Yok & $\begin{array}{l}\text { Müellif: Abdullah } \\
\text { Zahidî }\end{array}$ & Yok \\
\hline 21 & $\begin{array}{l}\text { Millet } \\
\text { Kütüphanesi Ali } \\
\text { Emiri Efendi, } \\
\text { Manzum } 1398\end{array}$ & $\begin{array}{l}\text { Gazavât-1 } \\
\text { Nebî (Siyer-i } \\
\text { Nebî) }\end{array}$ & $\begin{array}{l}\text { Müellif: } \\
\text { Muhammed } \\
\text { Müstensih: Seyyid } \\
\text { Abdullah }\end{array}$ & $\begin{array}{l}\text { Müellif: Niyâzî } \\
\text { Müstensih: Seyyid } \\
\text { Abdullah }\end{array}$ & $\begin{array}{l}\text { Yazmada İstinsah: } 959 \text { [1551] } \\
\text { tarihinde istinsah edilmiş bir } \\
\text { nüshadan } 1222^{\prime} \text { de [1807] } \\
\text { çoğaltılmış }\end{array}$ \\
\hline 22 & $\begin{array}{l}\text { Sül. Ktp. Bağdatlı } \\
\text { Vehbi, No: } 1544\end{array}$ & Manzûm Siyer & Yok & Yok & Yok \\
\hline 23 & $\begin{array}{l}\text { Sül. Ktp. Mehmed } \\
\text { Zeki Pakalın, No: } \\
154\end{array}$ & $\begin{array}{l}\text { Siyer-i Nebi } \\
\text { (Manzum) }\end{array}$ & $\begin{array}{l}\text { Müellif: } \\
\text { Muhammed }\end{array}$ & $\begin{array}{l}\text { Velî, Muhammed } \\
\text { adına kayıtlı }\end{array}$ & $\begin{array}{l}\text { Eserin Telif Y1l1 402a son } \\
\text { beyitte: } 872 \text { [1467] } \\
\text { Diğerleri: Yok }\end{array}$ \\
\hline 24 & $\begin{array}{l}\text { Sül. Ktp. Yazma } \\
\text { Bağışlar, No: } 1725\end{array}$ & $\begin{array}{l}\text { Siyer-i Nebiye } \\
\text { Aid Bir } \\
\text { Manzume }\end{array}$ & Yok & Yok & Yok \\
\hline 25 & $\begin{array}{l}\text { Sül. Ktp. Yazma } \\
\text { Bağışlar, No: } 3378\end{array}$ & $\begin{array}{l}\text { Siyerü'n-Nebi } \\
\text { (S.A.V.) }\end{array}$ & $\begin{array}{l}\text { Müstensih: } \\
\text { Muhammed bin } \\
\text { Murâd }\end{array}$ & $\begin{array}{l}\text { Velî, Muhammed } \\
\text { adına kayıtlı }\end{array}$ & Yazmada İstinsah: 1066 [1655] \\
\hline 26 & $\begin{array}{l}\text { Sül. Ktp.Yazma } \\
\text { Bağışlar, No: } 3916\end{array}$ & $\begin{array}{l}\text { Siyerü'n-Nebi- } \\
\text { Manzum }\end{array}$ & $\begin{array}{l}\text { Müellif: } \\
\text { Abdurrahman }\end{array}$ & $\begin{array}{l}\text { Müellif: } \\
\text { Abdurrahman }\end{array}$ & Yok \\
\hline 27 & $\begin{array}{l}\text { Sül. Ktp.Yazma } \\
\text { Bağışlar, No: } 4332\end{array}$ & Siretü'n-Nebi & $\begin{array}{l}\text { Müstensih: } \\
\text { Muhammed bin } \\
\text { İbrahim }\end{array}$ & $\begin{array}{l}\text { Velî, Muhammed } \\
\text { adına kayıtlı }\end{array}$ & Yazmada İstinsah: 1097 [1685] \\
\hline 28 & $\begin{array}{l}\text { Topkapı Sarayı } \\
\text { Müzesi Hazine } \\
\text { Kitaplığı TSMK, } \\
2287 \text { H. } 233\end{array}$ & Sîret en-Nebî & $\begin{array}{l}\text { Müellif: } \\
\text { Muhammed } \\
\text { Müstensih: Hasan }\end{array}$ & $\begin{array}{l}\text { Müellifi } \\
\text { bulunmayan bir } \\
\text { manzum Siyer } \\
\text { tercümesi olarak } \\
\text { kayıtlı }\end{array}$ & Yok \\
\hline
\end{tabular}




\begin{tabular}{|c|c|c|c|c|c|}
\hline 29 & $\begin{array}{l}\text { Türk Dil Kurumu } \\
\text { Yazmaları, } \\
\text { Yz.A.338 }\end{array}$ & Siyer-i Nebî & Yok & Müellif: Âşıkî & Yok \\
\hline 30 & $\begin{array}{l}\text { TYEKB Arşiv No } \\
05 \text { Ba } 1460\end{array}$ & $\begin{array}{l}\text { Manzûm } \\
\text { Siyer-i Nebi }\end{array}$ & $\begin{array}{l}\text { Sahibi } \\
\text { (Müstensihi): } \\
\text { İmam es-Seyyid } \\
\text { Hasan Efendi }\end{array}$ & $\begin{array}{l}\text { Yazar: Mollâ Velî } \\
\text { Efendî }\end{array}$ & $\begin{array}{l}\text { Eserin Telif Y } 111218^{\mathrm{b}} \text { beşinci } \\
\text { beyitte: } 872 \text { [1467] } \\
\text { Yazmada İstinsah: } 1218 \text { [1803] } \\
\text { Yazmada İkinci Kez İstinsah: } \\
1246 \text { [1830] } \\
\text { Kütüphane Kaydında Telif: } \\
872 \text { [1467] }\end{array}$ \\
\hline 31 & $\begin{array}{l}\text { TYEKB } 06 \text { Mil Yz } \\
\text { A } 2630 / 2\end{array}$ & $\begin{array}{l}\text { Gazavât-1 Hz. } \\
\text { Alî (K.A.V.) }\end{array}$ & Yok & Yok & $\begin{array}{l}\text { Yazmada İstinsah: } 1283 \text { [1866] } \\
\text { Kütüphane Kaydında İstinsah: } \\
1283 \text { [1866] }\end{array}$ \\
\hline 32 & $\begin{array}{l}\text { TYEKB } 06 \text { Mil Yz } \\
\text { A } 2763 / 2\end{array}$ & $\begin{array}{l}\text { Menâkıb-1 } \\
\text { Hazret-i Alî }\end{array}$ & Yok & Yok & Yok \\
\hline 33 & $\begin{array}{l}\text { TYEKB } 06 \text { Mil Yz } \\
\text { A } 2839\end{array}$ & $\begin{array}{l}\text { Manzûm } \\
\text { Siyer-i Nebî } \\
\text { (A.S.) }\end{array}$ & Yok & Yazar: Za'ifî & Yazmada İstinsah: 1195 [1780] \\
\hline 34 & $\begin{array}{l}\text { TYEKB } 06 \text { Mil Yz } \\
\text { A } 3062\end{array}$ & $\begin{array}{l}\text { Kissa-i } \\
\text { Ticaret-i } \\
\text { Mustafa (A.S.) }\end{array}$ & $\begin{array}{l}\text { Müstensih: İsmail } \\
\text { Zühdî }\end{array}$ & Yazar: İsmail Zühdî & $\begin{array}{l}\text { Yazmada İstinsah: } 1258 \text { [1842] } \\
\text { Kütüphane Kaydında İstinsah: } \\
1258 \text { [1839] }\end{array}$ \\
\hline 35 & $\begin{array}{l}\text { TYEKB } 06 \text { Mil Yz } \\
\text { A } 3115\end{array}$ & $\begin{array}{l}\text { Kısas-1 Sülehâ } \\
\text { ve Urefâ }\end{array}$ & $\begin{array}{l}\text { Sahibi } \\
\text { (Müstensihi): } \\
\text { Ahmed Efendi bin } \\
\text { Ömer }\end{array}$ & Yazar: Za'ifî & $\begin{array}{l}\text { Kütüphane Kaydında İstinsah: } \\
1217 \text { [1802] }\end{array}$ \\
\hline 36 & $\begin{array}{l}\text { TYEKB } 06 \text { Mil Yz } \\
\text { A } 3822\end{array}$ & $\begin{array}{l}\text { Kissa-i Siyer-i } \\
\text { Nebi }\end{array}$ & Yok & $\begin{array}{l}\text { Yazar: Za'ifî Pîr } \\
\text { Mehmed bin } \\
\text { Evrânôs bin } \\
\text { Nûreddîn bin el- } \\
\text { Fâris }\end{array}$ & Yok \\
\hline 37 & $\begin{array}{l}\text { TYEKB } 06 \text { Mil Yz } \\
\text { A } 3823\end{array}$ & Siyer-i Nebi & Yok & $\begin{array}{l}\text { Yazar: Za'ifî Pîr } \\
\text { Mehmed bin } \\
\text { Evrânôs bin } \\
\text { Nûreddîn bin el- } \\
\text { Fâris }\end{array}$ & Yok \\
\hline 38 & $\begin{array}{l}\text { TYEKB } 06 \text { Mil Yz } \\
\text { A } 3824\end{array}$ & Siyer-i Nebi & Yok & $\begin{array}{l}\text { Yazar: Za'ifî Pîr } \\
\text { Mehmed bin } \\
\text { Evrânôs bin } \\
\text { Nûreddîn bin el- }\end{array}$ & Yok \\
\hline
\end{tabular}


Bahseden Çalışmalar ve Sîret'in Nüsha Kayıtları-II

\begin{tabular}{|c|c|c|c|c|c|}
\hline & & & & Fâris & \\
\hline 39 & $\begin{array}{l}\text { TYEKB } 06 \text { Mil Yz } \\
\text { A } 3941\end{array}$ & Siyer & Yok & Yok & Yok \\
\hline 40 & $\begin{array}{l}\text { TYEKB } 06 \text { Mil Yz } \\
\text { A } 5428\end{array}$ & $\begin{array}{l}\text { Terceme-i } \\
\text { Siyer-i Nebi }\end{array}$ & $\begin{array}{l}\text { Müstensih: } \\
\text { Başmakçılı Hâfız } \\
\text { Hüseyin-zâde }\end{array}$ & $\begin{array}{l}\text { Yazar: Darîr } \\
\text { Mustafa bin Ömer } \\
\text { Erzûrûmî }\end{array}$ & $\begin{array}{l}\text { Yazmada İstinsah: } 1240 \text { [1824] } \\
\text { ve } 1241 \text { [1825] } \\
\text { Kütüphane Kaydında İstinsah: } \\
1241 \text { [1825] }\end{array}$ \\
\hline 41 & $\begin{array}{l}\text { TYEKB } 06 \text { Mil Yz } \\
\text { A } 6547\end{array}$ & $\begin{array}{l}\text { Terceme-i } \\
\text { Siyer-i Nebî }\end{array}$ & $\begin{array}{l}\text { Müstensih: Veys } \\
\text { ibn Mustafa Beg }\end{array}$ & $\begin{array}{l}\text { Yazar: Veys bin } \\
\text { Mustafâ }\end{array}$ & $\begin{array}{l}\text { Yazmada İstinsah: } 1167 \text { [1753] } \\
\text { Kütüphane Kaydında İstinsah: } \\
1162 \text { [1748] }\end{array}$ \\
\hline 42 & $\begin{array}{l}\text { TYEKB } 06 \text { Mil Yz } \\
\text { A } 6712\end{array}$ & $\begin{array}{l}\text { Menâkıb- } \\
\text { name }\end{array}$ & Yok & Yok & Yok \\
\hline 43 & $\begin{array}{l}\text { TYEKB } 06 \text { Mil Yz } \\
\text { A } 7004\end{array}$ & $\begin{array}{l}\text { Menâkıb- } \\
\text { nâme }\end{array}$ & Yok & Yok & Yok \\
\hline 44 & $\begin{array}{l}\text { TYEKB } 06 \text { Mil Yz } \\
\text { A } 7167\end{array}$ & Sîretü'n-Nebî & $\begin{array}{l}\text { Vakfeden:Kezban } \\
\text { Hatun }\end{array}$ & Yok & $\begin{array}{l}\text { Yzmada Vakıf Kaydı: } 1282 \\
\text { [1865] } \\
\text { Kütüphane Kaydında İstinsah: } \\
1282 \text { [1866] }\end{array}$ \\
\hline 45 & $\begin{array}{l}\text { TYEKB } 06 \text { Mil Yz } \\
\text { A } 8471\end{array}$ & $\begin{array}{l}\text { Terceme-i } \\
\text { Siyeri'n-Nebî }\end{array}$ & Yok & $\begin{array}{l}\text { Yazar: Darîr } \\
\text { Mustafa bin Yûsuf } \\
\text { Erzûrûmî }\end{array}$ & Yok \\
\hline 46 & $\begin{array}{l}\text { TYEKB } 06 \text { Mil Yz } \\
\text { A } 8631 / 2\end{array}$ & $\begin{array}{l}\text { Manzûme-i } \\
\text { Hatîcetü'l- } \\
\text { Kübrâ }\end{array}$ & Yok & Yok & Yok \\
\hline 47 & $\begin{array}{l}\text { TYEKB } 06 \text { Mil Yz } \\
\text { A } 8778\end{array}$ & $\begin{array}{l}\text { Kitâb- } \\
1 \text { Siretü'n-Nebî }\end{array}$ & Yok & Müstensih: Ali-zâde & Yok \\
\hline 48 & $\begin{array}{l}\text { TYEKB } 06 \text { Mil Yz } \\
\text { A } 8940\end{array}$ & $\begin{array}{l}\text { Ceng-nâme-i } \\
\text { Hz. Alî }\end{array}$ & Yok & Yok & Yok \\
\hline 49 & $\begin{array}{l}\text { TYEKB } 06 \text { Mil Yz } \\
\text { A } 8902\end{array}$ & $\begin{array}{l}\text { Manzûme-i } \\
\text { Hazret-i } \\
\text { Hadîcetü'l- } \\
\text { Kübrâ }\end{array}$ & Yok & Yok & Yok \\
\hline 50 & $\begin{array}{l}\text { TYEKB } 06 \text { Mil Yz } \\
\text { A 9105/3 }\end{array}$ & $\begin{array}{l}\text { Gazâ-i Benî } \\
\text { Kureyze }\end{array}$ & $\begin{array}{l}\text { Sahibi } \\
\text { (Müstensihi): } \\
\text { Hüseyin ibn } \\
\text { Hasan }\end{array}$ & Yok & Yazmada İstinsah: 1250 [1834] \\
\hline
\end{tabular}




\begin{tabular}{|c|c|c|c|c|c|}
\hline & $\begin{array}{l}\text { TYEKB } 06 \text { Mil Yz } \\
\text { A 9105/4 }\end{array}$ & $\begin{array}{l}\text { Kissa-i Hazret- } \\
\text { i Ömer }\end{array}$ & & & \\
\hline 51 & $\begin{array}{l}\text { TYEKB } 06 \text { Mil Yz } \\
\text { B } 1073\end{array}$ & Siretü'n-Nebî & $\begin{array}{l}\text { Müellif: } \\
\text { Muhammed }\end{array}$ & Yok & Yok \\
\hline 52 & $\begin{array}{l}\text { TYEKB } 06 \text { Mil Yz } \\
\text { B } 274\end{array}$ & $\begin{array}{l}\text { Siyer-i Nebî } \\
\text { Tercemesi }\end{array}$ & Yok & $\begin{array}{l}\text { Yazar: Darîr } \\
\text { Mustafa bin Yûsuf } \\
\text { Erzûrûmî }\end{array}$ & Yok \\
\hline 53 & $\begin{array}{l}\text { TYEKB } 06 \text { Mil Yz } \\
\text { B } 360\end{array}$ & Siretü'n-Nebi & $\begin{array}{l}\text { Müellif: } \\
\text { Muhammed } \\
\text { Müstensih: } \\
\text { Muhammed bin } \\
\text { Hasan bin } \\
\text { Mahmud }\end{array}$ & $\begin{array}{l}\text { Yazar: Mehmed } \\
\text { Halîfe } \\
\text { Müstensih: } \\
\text { Muhammed bin } \\
\text { Hasan }\end{array}$ & $\begin{array}{l}\text { Eserin Telif Y1l1 416a yedinci } \\
\text { beyitte: } 872 \text { [1467] } \\
\text { Yazmada İstinsah: } 1182 \text { [1768] } \\
\text { Kütüphane Kaydında İstinsah: } \\
1182 \text { [1768] }\end{array}$ \\
\hline 54 & $\begin{array}{l}\text { TYEKB } 06 \text { Mil Yz } \\
\text { B } 310\end{array}$ & Siyretü'n-Nebî & $\begin{array}{l}\text { Müstensih: Hâfız } \\
\text { Osman }\end{array}$ & $\begin{array}{l}\text { Yazar: Mehmed } \\
\text { Halîfe } \\
\text { Müstensih: Seyyid } \\
\text { Hafız Osman }\end{array}$ & $\begin{array}{l}\text { Eserin Telif Y } 111341^{\mathrm{b}} \text { yirmi } \\
\text { altıncı beyitte: } 872 \text { [1467] } \\
\text { Yazmada İstinsah: } 1217 \text { [1802] } \\
\text { Kütüphane Kaydında İstinsah: } \\
1217 \text { [1802] }\end{array}$ \\
\hline 55 & $\begin{array}{l}\text { TYEKB } 06 \text { Mil Yz } \\
\text { B } 370\end{array}$ & Siretü'n-Nebi & $\begin{array}{l}\text { Müstensih: } \\
\text { Mustafa }\end{array}$ & $\begin{array}{l}\text { Yazar: Mehmed } \\
\text { Halîfe } \\
\text { Müstensih: Mustafa } \\
\text { Hanif }\end{array}$ & $\begin{array}{l}\text { Yazmada İstinsah: } 1279 \text { [1862] } \\
\text { Kütüphane Kaydında İstinsah: } \\
1279[1862]\end{array}$ \\
\hline 56 & $\begin{array}{l}\text { TYEKB } 06 \text { Mil Yz } \\
\text { B 37/1 }\end{array}$ & Gazavât-nâme & $\begin{array}{l}\text { Müstensih: Hâfız } \\
\text { Hasan bin } \\
\text { Abdurrahmân }\end{array}$ & $\begin{array}{l}\text { Yazar: } \\
\text { Abdurrahmân. } \\
\text { Müstensih: Hasan } \\
\text { bin Abdurrahmân. }\end{array}$ & $\begin{array}{l}\text { Yazmada İstinsah: } 1181 \text { [1767] } \\
\text { Kütüphane Kaydında İstinsah: } \\
1181 \text { [1767] }\end{array}$ \\
\hline 57 & $\begin{array}{l}\text { TYEKB } 06 \text { Mil Yz } \\
\text { B } 453\end{array}$ & Siyretü'n-Nebî & Yok & $\begin{array}{l}\text { Yazar: Mehmed } \\
\text { Halîfe }\end{array}$ & Yok \\
\hline 58 & TYEKB 19 Hk 1122 & $\begin{array}{l}\text { Terceme-i } \\
\text { Siyer-i Nebi }\end{array}$ & $\begin{array}{l}\text { Müellif: } \\
\text { Muhammed } \\
\text { Müstensih: Figânî- } \\
\text { zâde Çorumlu } \\
\text { Abdullâh bin } \\
\text { Mahmûd bin Ebû } \\
\text { Bekr }\end{array}$ & $\begin{array}{l}\text { Müstensih: } \\
\text { Figanîzade } \\
\text { Abdullah bin } \\
\text { Mahmûd bin Bekir. }\end{array}$ & $\begin{array}{l}\text { Yazmada İstinsah: } 1207 \text { [1792] } \\
\text { Kütüphane Kaydında İstinsah: } \\
1207 \text { [1791] }\end{array}$ \\
\hline 59 & $\begin{array}{l}\text { TYEKB } 55 \mathrm{Hk} \\
458 / 11\end{array}$ & Cenk-nâme & Yok & Yok & $\begin{array}{l}\text { Yazmada Dört İstinsah Var: } \\
1187 \text { [1773] } 1186 \text { [1772] } 1187 \\
\text { [1773] } 1184 \text { [1770] }\end{array}$ \\
\hline
\end{tabular}


Bahseden Çalışmalar ve Sîret'in Nüsha Kayıtları-II

\begin{tabular}{|c|c|c|c|c|c|}
\hline & & & & & $\begin{array}{l}\text { Kütüphane Kaydında İstinsah: } \\
1187 \text { [1773] }\end{array}$ \\
\hline 60 & $\begin{array}{l}\text { YK Sermet Çifter } \\
\text { Araş. Ktp.TY. No: } \\
823\end{array}$ & Siyer-i Nebî & $\begin{array}{l}\text { Sahibi: } \\
\text { Muhammed Molla }\end{array}$ & Yok & $\begin{array}{l}\text { Yazmada Sahiplik: } 1115 \text { [1703] } \\
\text { Kütüphane Kaydında İstinsah: } \\
\text { 16. Yüzyıl Olabilir }\end{array}$ \\
\hline 61 & $\begin{array}{l}\text { YK Sermet Çifter } \\
\text { Araş. Ktp.TY. No: } \\
859\end{array}$ & Siyer-i Nebî & Yok & Müellifi: Hasanoğlu & $\begin{array}{l}\text { Kütüphane Kaydında İstinsah: } \\
17 \text { ya da } 18 \text { Yüzyıl Olabilir }\end{array}$ \\
\hline 62 & $\begin{array}{l}\text { Gazi Husrev- } \\
\text { Begova Biblioteka } \\
\text { u Sarajevu, No: } \\
4613\end{array}$ & Siret en-nebî & $\begin{array}{l}\text { Müellif: } \\
\text { Muhammed }\end{array}$ & Müellif: Mehmed & $\begin{array}{l}\text { Eserin Telif Y1lı 399a dördüncü } \\
\text { beyitte: } 872 \text { [1467] } \\
\text { Yazmada İstinsah: } 1272 \text { [1855] } \\
\text { Kütüphane Kaydında İstinsah: } \\
1272 \text { [1855] } \\
\text { Kütüphane Kaydında Telif: } \\
872 \text { [1467] }\end{array}$ \\
\hline 63 & $\begin{array}{l}\text { Macar Bilimler } \\
\text { Akademisi } \\
\text { Kütüphanesi, } \\
\text { Torok Ms F } 045\end{array}$ & Sîretü'n-Nebî & $\begin{array}{l}\text { Müellif: } \\
\text { Muhammed }\end{array}$ & Müellif: Muhammed & Yok \\
\hline 64 & $\begin{array}{l}\text { Staatsbibliothek, } \\
\text { Berlin, } \\
\text { Ms.or.fol.3333 }\end{array}$ & Siyer-i Nebi & $\begin{array}{l}\text { Müellif: } \\
\text { Muhammed }\end{array}$ & $\begin{array}{l}\text { Müellif: Mehmed } \\
\text { (Muhammed) }\end{array}$ & $\begin{array}{l}\text { Eserin Telif Yılı } 418^{\text {b }} \\
\text { dokuzuncu beyitte: } 872 \text { [1467] } \\
\text { Kütüphane Kaydında Telif: } \\
872 \text { [1467] } \\
\text { Diğerleri: Yok }\end{array}$ \\
\hline 65 & $\begin{array}{l}\text { Staatsbibliothek, } \\
\text { Berlin, } \\
\text { Ms.or.oct.2083 }\end{array}$ & $\begin{array}{l}\text { Dâsitân-1 } \\
\text { Gazavât-1 } \\
\text { Resûl As. Alâ } \\
\text { Kal'at-1 } \\
\text { Mecûsiyân } \\
\text { Dâsitân-1 } \\
\text { İslâm-1 } \\
\text { Hazret-i Ömer } \\
\begin{array}{l}\text { Dâsitân-1 } \\
\text { Gazavât-1 } \\
\text { Resûlüllâh }\end{array} \\
\text { Dâsitân-1 } \\
\text { Abdurrahmân } \\
\text { bin Ebî Bekr }\end{array}$ & Yok & Yok & Yok \\
\hline
\end{tabular}




\begin{tabular}{|c|c|c|c|c|c|}
\hline 66 & $\begin{array}{l}\text { Staatsbibliothek, } \\
\text { Berlin, } \\
\text { Ms.or.quart.1550 }\end{array}$ & $\begin{array}{l}\text { Kissa-i Nikâh- } \\
1 \text { Hazret-i } \\
\text { Hadîce }\end{array}$ & $\begin{array}{l}\text { Müellif: } \\
\text { Muhammed }\end{array}$ & $\begin{array}{l}\text { Müellif: Mehmed } \\
\text { (Muhammed) }\end{array}$ & $\begin{array}{l}\text { (Hanna Sohrweide'ın Türkische } \\
\text { Handschriften adlı eserine } \\
\text { atfen) Yazmada Telif: } 872 \\
\text { [1467] }\end{array}$ \\
\hline 67 & $\begin{array}{l}\text { Edirne Selimiye } \\
\text { Ktp. } 22 \text { Sel } 2532\end{array}$ & $\begin{array}{l}\text { Kitab Siyer el } \\
\text { Nebi }\end{array}$ & $\begin{array}{l}\text { Yazar: } \\
\text { Abdurrahman }\end{array}$ & $\begin{array}{l}\text { Yazar: } \\
\text { Abdurrahman }\end{array}$ & $\begin{array}{l}\text { Bazı yazma nüshalarda } \\
\text { bulunan eserin telif yılının } \\
\text { geçtiği sondaki bölüm } \\
\text { çıkarılmıştır. } \\
\text { Taş Baskı:1284 [1867] } \\
\text { Kütüphane Kaydında:1284 } \\
\text { [1867] }\end{array}$ \\
\hline 68 & $\begin{array}{l}\text { İrcica } \\
\text { Ktp.297.63.MU.S }\end{array}$ & Siyer-i Nebi & $\begin{array}{l}\text { Yazar: } \\
\text { Abdurrahman }\end{array}$ & $\begin{array}{l}\text { Yazar: Mustafa } \\
\text { Nazif Kadırgavi }\end{array}$ & $\begin{array}{l}\text { Bazı yazma nüshalarda } \\
\text { bulunan eserin telif yılının } \\
\text { geçtiği sondaki bölüm } \\
\text { çıarılmıştır. } \\
\text { Taş Baskı: Tarihsiz } \\
\text { Kütüphane Kaydında: Yok }\end{array}$ \\
\hline 69 & $\begin{array}{l}\text { İrcica Ktp. } \\
\text { 297.63.MU.S }\end{array}$ & Siyer-i Nebi & $\begin{array}{l}\text { Yazar: } \\
\text { Abdurrahman }\end{array}$ & $\begin{array}{l}\text { Yazar: Mustafa } \\
\text { Nazif Kadırgavi }\end{array}$ & $\begin{array}{l}\text { Bazı yazma nüshalarda } \\
\text { bulunan eserin telif yılının } \\
\text { geçtiği sondaki bölüm } \\
\text { çıkarılmıştır. } \\
\text { Taş Baskı: } 1332 \text { [1913] } \\
\text { Kütüphane Kaydında: } 1332 \\
\text { [1913] }\end{array}$ \\
\hline 70 & $\begin{array}{l}\text { İstanbul BB } \\
\text { Atatürk Kitaplığ1 } \\
\text { Demirbaş No: } \\
\text { DA_0178 }\end{array}$ & $\begin{array}{l}\text { Kitab-1 } \\
\text { Siyerü'n-Nebi }\end{array}$ & $\begin{array}{l}\text { Yazar: } \\
\text { Abdurrahman }\end{array}$ & Yok & $\begin{array}{l}\text { Bazı yazma nüshalarda } \\
\text { bulunan eserin telif yılının } \\
\text { geçtiği sondaki bölüm } \\
\text { çıkarılmıştır. } \\
\text { Taş Baskı: } 1308 \text { [1890] } \\
\text { Kütüphane Kaydında: } 1308 \\
\text { [1890] }\end{array}$ \\
\hline
\end{tabular}

